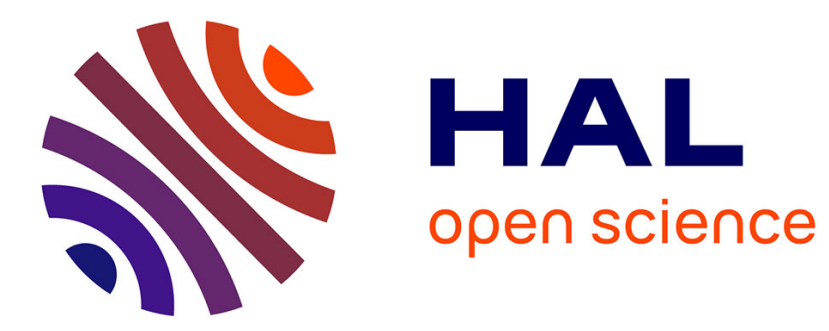

\title{
Synthesis of Pyrimidine-Containing Nucleoside $\beta$-(R/S)-Hydroxyphosphonate Analogues
}

Maïa Meurillon, Laurent Chaloin, Christian Perigaud, Suzanne Peyrottes

\section{To cite this version:}

Maïa Meurillon, Laurent Chaloin, Christian Perigaud, Suzanne Peyrottes. Synthesis of PyrimidineContaining Nucleoside $\beta$-(R/S)-Hydroxyphosphonate Analogues. European Journal of Organic Chemistry, 2011, 20-21, pp.3794-3802. 10.1002/ejoc.201100219 . hal-00616845

\section{HAL Id: hal-00616845 https://hal.science/hal-00616845}

Submitted on 28 May 2020

HAL is a multi-disciplinary open access archive for the deposit and dissemination of scientific research documents, whether they are published or not. The documents may come from teaching and research institutions in France or abroad, or from public or private research centers.
L'archive ouverte pluridisciplinaire $\mathbf{H A L}$, est destinée au dépôt et à la diffusion de documents scientifiques de niveau recherche, publiés ou non, émanant des établissements d'enseignement et de recherche français ou étrangers, des laboratoires publics ou privés. 


\title{
Synthesis of Pyrimidine-Containing Nucleoside $\beta-(R / S)$-Hydroxyphosphonate Analogues
}

\author{
Maïa Meurillon, ${ }^{[a]}$ Laurent Chaloin, ${ }^{[b]}$ Christian Périgaud, ${ }^{[a]}$ and Suzanne Peyrottes*[a]
}

Keywords: Nucleotides / Reduction / Molecular modeling / Phosphonates / Ribonucleosides

A concise route to nucleoside $\beta$-hydroxyphosphonate analogues is described. The use of a nucleoside $\beta$-ketophosphonate as the key intermediate allowed both the $(R)$ and $(S)$ isomers of $\beta$-hydroxyphosphonate analogues in the pyrimidine series to be accessed. Such derivatives may be considered as stable mimics of $5^{\prime}$-monophosphate nucleosides and, therefore, could be the starting point for the development of potential therapeutic agents.

\section{Introduction}

Nucleos(t)idic analogues are an important family of bioactive compounds widely used as anticancer ${ }^{[1]}$ and antiviral drugs. ${ }^{[2]}$ Within this research area, our group has focused its attention on the development of nucleoside phosphonate derivatives containing a chemically and enzymatically stable $\mathrm{P}-\mathrm{C}$ bond rather than a $\mathrm{P}-\mathrm{O}$ one. These analogues may be viewed as structural isosteres of nucleoside monophosphate and present the advantage of skipping the initial phosphorylation step, which is often considered as the rate-limiting one in the conversion to the $5^{\prime}$-triphosphate derivative. With the aim to discover new potential bioactive agents, our interest was focused on nucleosidic $\beta$-modified-phosphonate analogues where a polar group (i.e., hydroxy group) at the $5^{\prime}$-position could play a role similar to that of the $5^{\prime}$-oxygen atom in native nucleoside monophosphate. In this respect, nucleoside $\beta$-hydroxyphosphonate analogues have been previously obtained by using an ex-chiral pool synthesis. ${ }^{[3]}$ Despite our efforts to modify the $5^{\prime}$-carbon configuration, this first pathway only permitted the isolation of the $\beta$ - $(S)$-hydroxyphosphonate isomer, and we decided to explore another synthetic strategy aiming at the isolation of the two diastereoisomers. Several protocols for the efficient synthesis of hydroxyphosphonate derivatives have been described, ${ }^{[4]}$ including oxirane ring opening, phosphonylation of carbonyl intermediates, diastereoselective reduction of ketophosphonates, and catalytic hydrogenation of enol-ester phosphonates. Among them, the most efficient and common pathway to reach both $(R)$ and $(S)$

[a] UMR 5247 CNRS-UM1-UM2, IBMM, Nucleosides \& Phosphorylated Effectors Team, University Montpellier 2, cc1705, place E. Bataillon, 34095 Montpellier, France

Fax: +33-467042029

E-mail: peyrottes@univ-montp2.fr

[b] UMR 5236 CNRS, CPBS, Biophysic \& Bioinformatics Team, 1919, route de Mende, 34293 Montpellier, France

Supporting information for this article is available on the WWW under http://dx.doi.org/10.1002/ejoc.201100219. isomers appeared to be the reduction of the corresponding $\beta$-ketophosphonate derivative. Thereby, we decided to optimize the synthesis of a nucleoside $\beta$-ketophosphonate (hitherto unknown) as a key intermediate, and then to perform its reduction. Molecular modeling studies were carried out to propose mechanistic insights of the stereoselective reduction step. Finally, transformation of the uracil nucleobase into cytosine would lead to the cytidine derivatives.

\section{Results and Discussion}

We first focused on the synthesis of the key intermediate, that is, the $\beta$-ketophosphonate, ${ }^{[5]}$ using benzyl-2-phenylacetate (1) as the starting material (Scheme 1). The latter is a simple and easily available model. On the basis of literature data, ${ }^{[6]}$ various reaction conditions were tested (Table 1), including the effect of the addition order and the preparation of the reagents, the number of equivalents, the temperature, as well as the hydrolysis mode at the end of the reaction course.

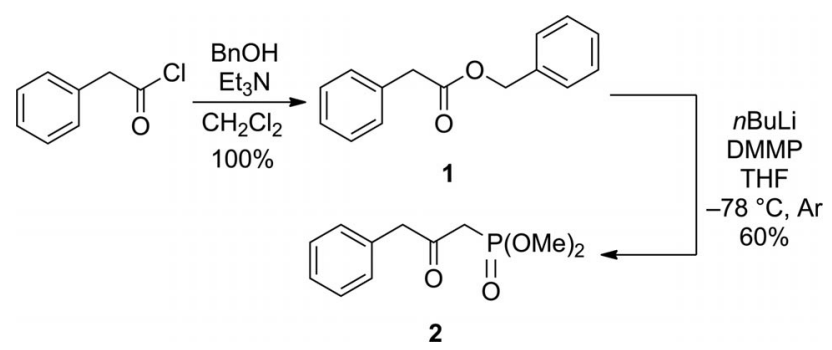

Scheme 1. Synthesis of $\beta$-ketophosphonate model 2

The best results were obtained when the benzyl ester was added over the lithio derivative in situ generated by the addition of $n \mathrm{BuLi}$ to an excess amount of commercially available dimethyl methylphosphonate (DMMP; Table 1, Entry 5). Then, the best procedure was applied to the synthesis of the uracil $\beta$-ketophosphonate nucleoside analogues 
Table 1. Optimization study for the synthesis of the $\beta$-ketophosphonate model 2.

\begin{tabular}{|c|c|c|c|c|c|}
\hline Entry & 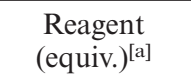 & Addition order & Experimental conditions & $\begin{array}{c}\text { Recovery of SM } \\
{[\%]^{[b]}}\end{array}$ & $\begin{array}{l}\text { Yield } \\
{[\%]^{[b]}}\end{array}$ \\
\hline 1 & $\begin{array}{l}\operatorname{DMMP}(1) \\
n \mathrm{BuLi}(1) \\
\mathrm{RCO}_{2} \mathrm{Bn}(1)\end{array}$ & $\mathrm{RCO}_{2} \mathrm{Bn}$ over lithio-anion & $\begin{array}{l}\text { anion } 1 \mathrm{~h},-50^{\circ} \mathrm{C} \text {; reaction } 2 \mathrm{~h} \text {, } \\
-78^{\circ} \mathrm{C} \text {, then warmed to } 0{ }^{\circ} \mathrm{C} \text {; } \\
\text { hydrolysis at } 0^{\circ} \mathrm{C} \text { with } \mathrm{NH}_{4} \mathrm{Cl}\end{array}$ & 75 & 16 \\
\hline 2 & $\begin{array}{l}\operatorname{DMMP}(1) \\
n \mathrm{BuLi}(1) \\
\mathrm{RCO}_{2} \mathrm{Bn}(1)\end{array}$ & lithio-anion over $\mathrm{RCO}_{2} \mathrm{Bn}$ & $\begin{array}{l}\text { anion } 1 \mathrm{~h},-50^{\circ} \mathrm{C} \text {; reaction } 2 \mathrm{~h} \text {, } \\
-78^{\circ} \mathrm{C} \text { then warmed to } 0{ }^{\circ} \mathrm{C} \text {; } \\
\text { hydrolysis at } 0^{\circ} \mathrm{C} \text { with } \mathrm{NH}_{4} \mathrm{Cl}\end{array}$ & 92 & 12 \\
\hline 3 & $\begin{array}{l}\operatorname{DMMP}(2.5) \\
n \operatorname{BuLi}(2.5) \\
\mathrm{RCO}_{2} \mathrm{Bn}(1)\end{array}$ & $\mathrm{RCO}_{2} \mathrm{Bn}$ over lithio-anion & $\begin{array}{l}\text { anion } 1 \mathrm{~h},-50^{\circ} \mathrm{C} \text {; reaction } 2 \mathrm{~h} \text {, } \\
-78^{\circ} \mathrm{C} \text { then warmed to } 0{ }^{\circ} \mathrm{C} \text {; } \\
\text { hydrolysis at } 0^{\circ} \mathrm{C} \text { with } \mathrm{NH}_{4} \mathrm{Cl}\end{array}$ & 41 & 57 \\
\hline 4 & $\begin{array}{l}\operatorname{DMMP}(2.5) \\
n \operatorname{BuLi}(2.5) \\
\mathrm{RCO}_{2} \mathrm{Bn}(1)\end{array}$ & lithio-anion over $\mathrm{RCO}_{2} \mathrm{Bn}$ & $\begin{array}{l}\text { anion } 1 \mathrm{~h},-50^{\circ} \mathrm{C} \text {; reaction } 2 \mathrm{~h} \text {, } \\
-78^{\circ} \mathrm{C} \text { then warmed to } 0^{\circ} \mathrm{C} \text {; } \\
\text { hydrolysis at } 0^{\circ} \mathrm{C} \text { with } \mathrm{NH}_{4} \mathrm{Cl}\end{array}$ & 63 & 34 \\
\hline 5 & $\begin{array}{l}\operatorname{DMMP}(2.5) \\
n \mathrm{BuLi}(2.5) \\
\mathrm{RCO}_{2} \mathrm{Bn}(1)\end{array}$ & $\mathrm{RCO}_{2} \mathrm{Bn}$ over lithio-anion & $\begin{array}{c}\text { anion } 30 \mathrm{~min},-78^{\circ} \mathrm{C} ; \\
\text { reaction } 5 \mathrm{~h},-78^{\circ} \mathrm{C} ; \\
\text { hydrolysis at }-78^{\circ} \mathrm{C} \text { with } \mathrm{NH}_{4} \mathrm{Cl}\end{array}$ & 37 & 60 \\
\hline 6 & $\begin{array}{l}\operatorname{DMMP}(1.2) \\
n \mathrm{BuLi}(1.1) \\
\mathrm{RCO}_{2} \mathrm{Bn}(1)\end{array}$ & $\mathrm{RCO}_{2} \mathrm{Bn}$ over lithio-anion & $\begin{array}{l}\text { anion } 30 \mathrm{~min},-78^{\circ} \mathrm{C} \text {; } \\
\text { reaction to r.t. over } 3 \mathrm{~h} \text {; } \\
\text { hydrolysis at r.t. with } 5 \% \text { citric acid }\end{array}$ & 69 & 34 \\
\hline 7 & $\begin{array}{l}\operatorname{DMMP}(2.5) \\
n \mathrm{BuLi}(2.5) \\
\mathrm{RCO}_{2} \mathrm{Bn}(1)\end{array}$ & lithio-anion over $\mathrm{RCO}_{2} \mathrm{Bn}$ & $\begin{array}{c}\text { anion } 30 \mathrm{~min},-78^{\circ} \mathrm{C} ; \\
\text { reaction } 2 \mathrm{~h},-78^{\circ} \mathrm{C} ; \\
\text { hydrolysis at }-78^{\circ} \mathrm{C} \text { with } \mathrm{NH}_{4} \mathrm{Cl}\end{array}$ & 53 & 38 \\
\hline 8 & $\begin{array}{l}\operatorname{DMMP}(2.5) \\
n \operatorname{BuLi}(2.5) \\
\mathrm{RCO}_{2} \mathrm{Bn}(1)\end{array}$ & lithio-anion over $\mathrm{RCO}_{2} \mathrm{Bn}$ & $\begin{array}{l}\text { anion } 30 \mathrm{~min},-78^{\circ} \mathrm{C} ; \\
\text { reaction at r.t.; } \\
\text { hydrolysis at r.t. with } \mathrm{NH}_{4} \mathrm{Cl}\end{array}$ & 27 & 50 \\
\hline
\end{tabular}

[a] DMMP = dimethyl methylphosphonate. [b] Isolated yield obtained after purification by column chromatography.

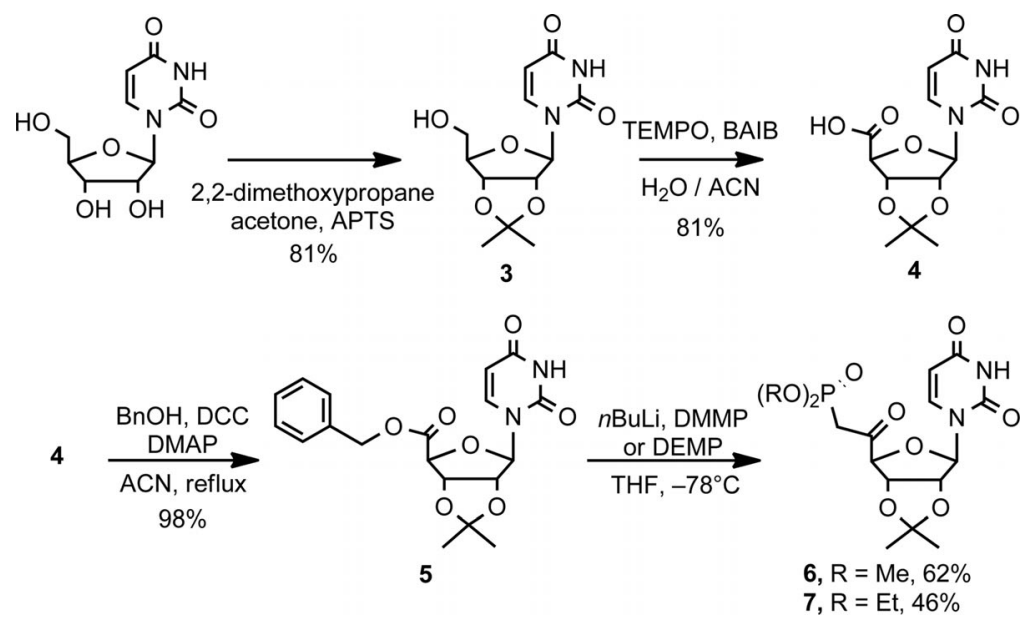

Scheme 2. Synthesis of nucleoside $\beta$-ketophosphonate intermediates 6 and 7.

(compounds 6 and 7, Scheme 2) starting from commercially available uridine.

Following the selective introduction of an isopropylidene protecting group onto the 2 '- and $3^{\prime}$-positions of uridine, the primary hydroxy function at the $5^{\prime}$-position was oxidized by using 2,2,6,6-tetramethylpiperidine-1-oxyl (TEMPO) and (diacetoxyiodo)benzene (BAIB) to lead to $5^{\prime}$-uronic acid 4 in $81 \%$ yield. ${ }^{[7]}$ This latter was esterified in the presence of benzyl alcohol, dicyclohexylcarbodiimide
(DCC), and 4-dimethylaminopyridine (DMAP) ${ }^{[8]}$ to obtain intermediate $\mathbf{5}$, which was then treated with the lithio-anion of dimethyl or diethyl methylphosphonate to give desired nucleoside $\beta$-ketophosphonates $\mathbf{6}$ and $\mathbf{7}$ in moderate yields (46 to $62 \%$ ). With these key intermediates in hand, we embarked on the study of their reduction into the corresponding nucleoside $\beta$-hydroxyphosphonate analogues by using dimethyl $\beta$-ketophosphonate derivative $\mathbf{6}$ as the model substrate. The ratio of $(R) /(S)$ diastereoisomers was determined 
by the integration of the corresponding ${ }^{1} \mathrm{H}$ NMR signals of the $6-\mathrm{H}$ proton (nucleobase, $\Delta \delta=0.17 \mathrm{ppm}$ for the two epimers) and attribution of the chirality was assessed after comparison of the spectroscopic data of the fully deprotected mixture (Table 2, Entry 1) with the previously obtained $\beta$ - $(S)$-isomer. ${ }^{[3]}$

Table 2. Study of the reduction conditions of the nucleoside $\beta$-ketophosphonate intermediate 6 .

\begin{tabular}{lccc}
\hline Entry & Experimental conditions & $\begin{array}{c}(S) /(R) \\
\text { ratio }^{\text {[a] }}\end{array}$ & $\begin{array}{c}\text { Yield } \\
{[\%]^{[\mathrm{b}]}}\end{array}$ \\
\hline 1 & $\mathrm{NaBH}_{4}, \mathrm{MeOH}$, r.t. & $70: 30$ & 47 \\
2 & $\mathrm{NaBH}_{4}, \mathrm{MeOH},-30{ }^{\circ} \mathrm{C}$ & $75: 25$ & 49 \\
3 & $\mathrm{NaBH}_{4},(-)$-tartaric acid, THF, $-30{ }^{\circ} \mathrm{C}$ & $89: 11$ & 88 \\
4 & $\mathrm{NaBH}_{4},(+)$-tartaric acid, THF, & $57: 43$ & 30 \\
5 & $-30^{\circ} \mathrm{C}$ & $73: 27$ & 50 \\
6 & $\mathrm{NaBH}_{4}, \mathrm{ZnCl}_{2}, \mathrm{MeOH},-30^{\circ} \mathrm{C}$ & $41: 59$ & 75 \\
\hline
\end{tabular}

[a] Ratio of $(R)$ vs. $(S)$ isomer was determined by integration of the corresponding ${ }^{1} \mathrm{H}$ NMR signals of $6-\mathrm{H}$. [b] Isolated yield obtained after column chromatography.
Standard conditions (Table 2, Entries $1 \& 2$ ) were firstly applied, which led to the $(S)$ diastereoisomer as the major product $(>70 \%)$ in modest yield, ${ }^{[9]}$ thus showing an important induction effect due to the substrate. Then, several attempts were carried out with the use of a chiral inductor generated in situ (Table 2, Entries $3 \& 4)^{[4 a, 10]}$ or chelating conditions (Table 2, Entries $5 \& 6)^{[11]}$ with the aim to improve the ratio of the two diastereoisomers in favor of the $\beta-(R)$ one. The use of $\mathrm{NaBH}_{4}$ in the presence of (-)-tartaric acid (Table 2, Entry 3 ) provided a better diastereoselectivity than under standard conditions and a higher yield. The relative reactivity was moderately inverted by replacing (-)tartaric acid by its (+)-isomer (Table 2, Entry 4), and in both cases the $(S)$ diastereoisomer was still the major product. Preferential formation of the $(R)$ isomer was only observed by using Luche conditions (Table 2, Entry 6). The presence of an almost stoichiometric quantity of the Lewis acid $\mathrm{CeCl}_{3}$ proved to be essential to reach good yield and preferential formation of the $(R)$ isomer, as a result of the chelated species where the metal joined the phosphanyl,

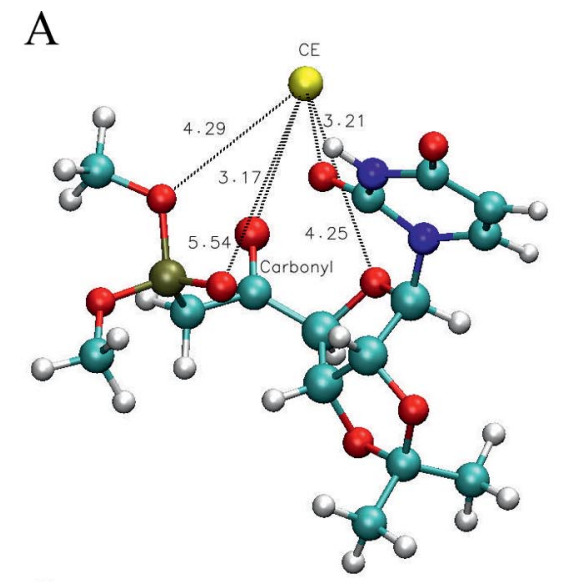

B
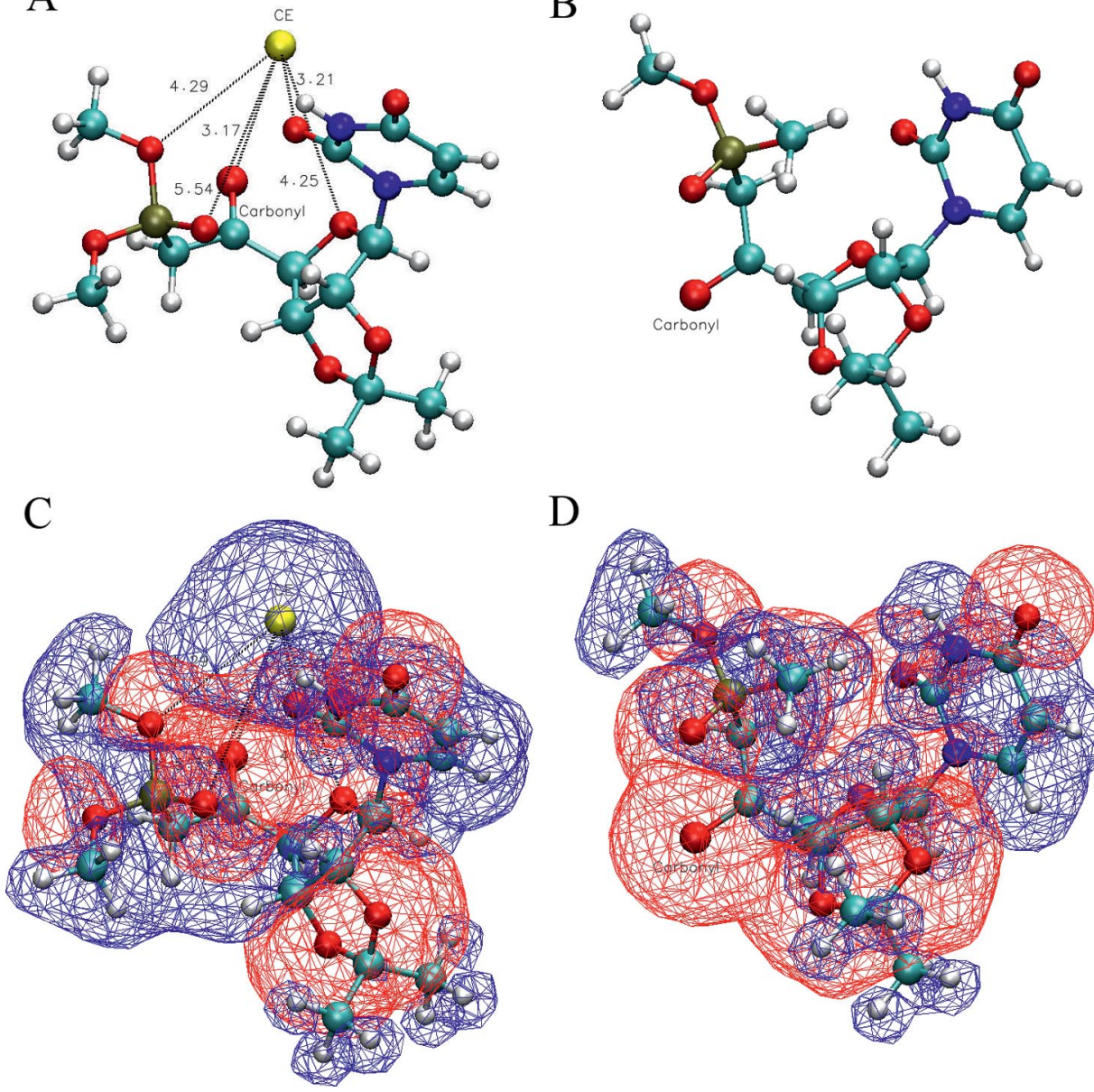

$\mathrm{D}$

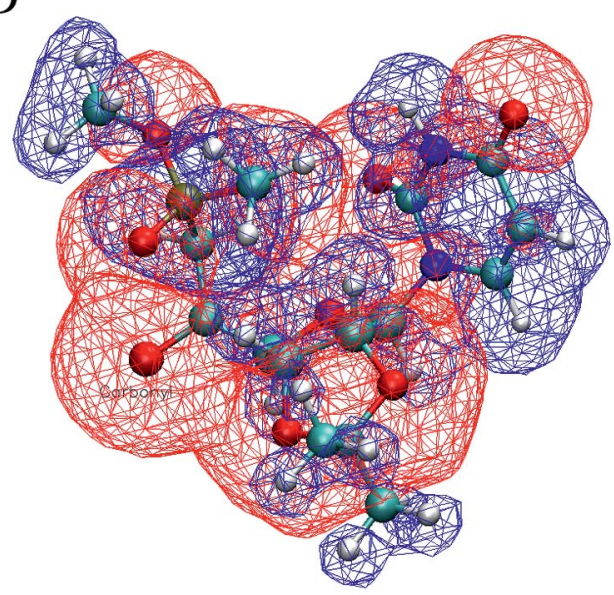

Figure 1. Molecular modeling of $\beta$-ketophosphonate intermediate $\mathbf{6}$ as represented in a ball-and-stick model after energy minimization: (A) In the presence of one cerium ion (yellow), the oxygen of the C-5' keto group is directed toward the cerium ion that is located on the opposite side of the protected ribose hydroxy groups; (B) without any cerium ion, the oxygen of the C-5' keto group (yellow circle) is located in the front plan of the molecule as the nucleobase. For each molecule (chelated or not), the spatial distribution of the electrostatic potential was calculated with APBS and is shown in panels C and D. The blue and red grids represent the positive and negative isosurface of the electrostatic potential at $+/-10 k_{\mathrm{b}} T / \mathrm{e}$. 
keto (C-5'), heterocyclic (C-2), and sugar oxygen atoms (Scheme 3 ). One could note that depending on the nature of the chelating metal $\left(\mathrm{Zn}^{2+}\right.$ or $\mathrm{Ce}^{3+}$; Table 2, Entry 5 or 6$)$, the opposite ratio of $(R)$ and $(S)$ isomers was observed. This might be attributed to steric effects (the cerium ion with a radius of $1.02 \AA$ is larger than zinc with a radius of $0.74 \AA$ ) and to the larger capacity of the cerium ion to chelate oxygen atoms compared to zinc. ${ }^{[12]}$ Furthermore, we assumed that under the Luche conditions, precoordination of the
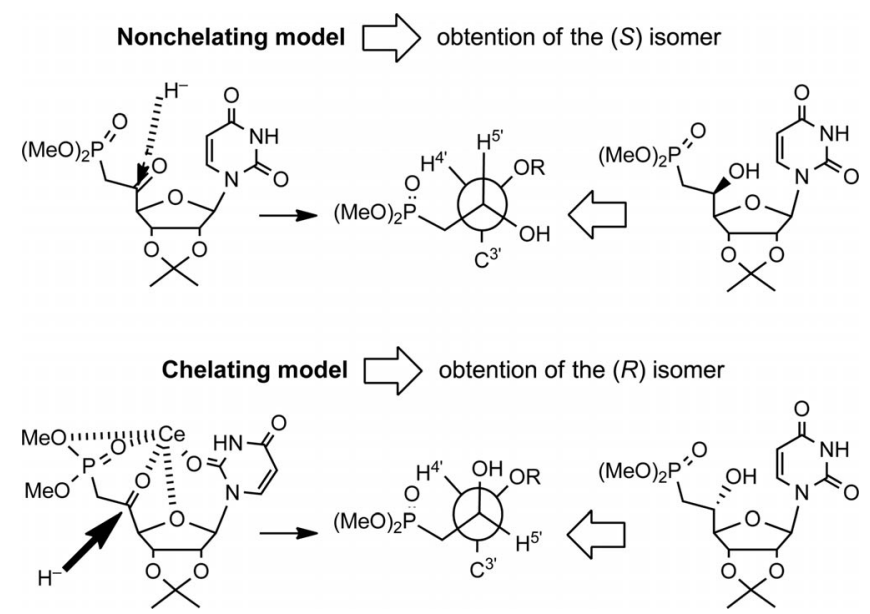

Scheme 3. Proposed mechanism for the preferential formation of the $(R)$ isomer assuming catalyst control and the $(S)$ isomer of the nucleoside $\beta$-hydroxyphosphonate analogues. substrate with the Lewis acids occurs first followed by the reduction process, whereas using the $\mathrm{ZnCl}_{2}-\mathrm{NaBH}_{4}$ complex, the metal ion does not bind strongly or sufficiently to induce a chelation-controlled reaction.

All these results allowed us to propose a mechanism for the two reduction reactions with respect to the stereocontrol observed and involving a strong facial discrimination towards attack of the hydride (Scheme 3). Within the nonchelating model, the presence of the bulky isopropylidene group on the front side and the fact that the nucleotide mainly exists as its anti conformer allowed the hydride to attack from the back side, whereas in the chelating model, the presence of the metal ion at the back face forced the nucleotide to adopt a syn conformation leading to hydride attack from the front side.

This proposed mechanism was supported by molecular modeling studies (Figure 1) of $\beta$-ketophosphonate intermediate 6 obtained in the presence of (Figure 1A) or without (Figure 1B) the cerium ion. Comparison of the two models clearly shows the opposite location of the $\mathrm{C}-5^{\prime}$ keto group, whereas they were oriented identically before energy minimization. Distances between the cerium and oxygen atoms were $3.17 \AA$ (C-5' keto group), $3.21 \AA$ (C-2 heterocyclic), $4.25 \AA$ (furanose ring), $4.28 \AA$ (phosphonate double bonded), and $5.54 \AA$ (methoxy groups). This indicates the electrostatic attraction of the cerium ion by the electron rich oxygen atoms. With its charge and atomic radius, the cerium took up a large space backwards (Figure 1A). This

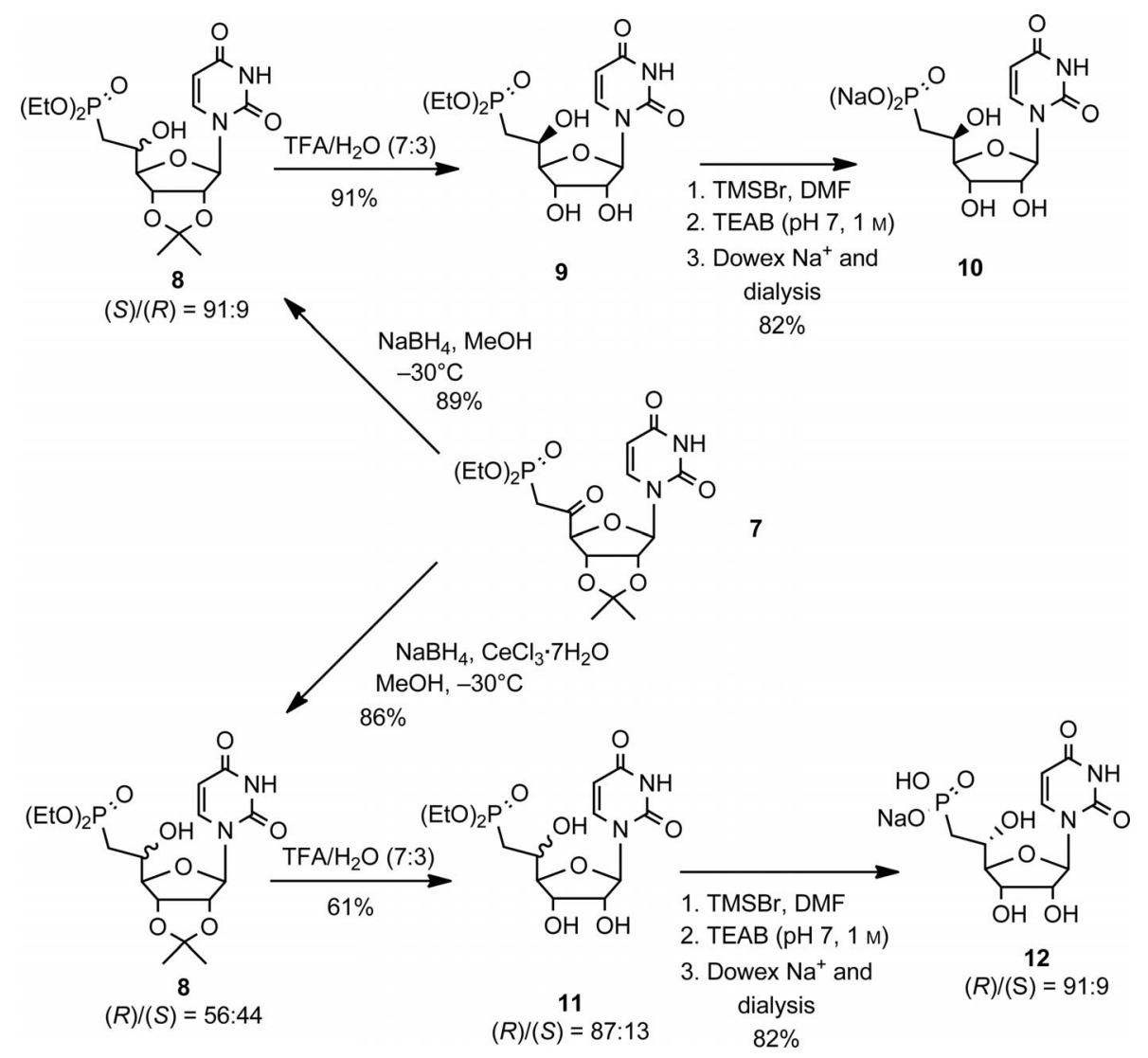

Scheme 4. Synthesis of nucleoside $\beta-(R)$ - and $\beta-(S)$-hydrophosphonate analogues $\mathbf{1 0}$ and $\mathbf{1 2}$. 

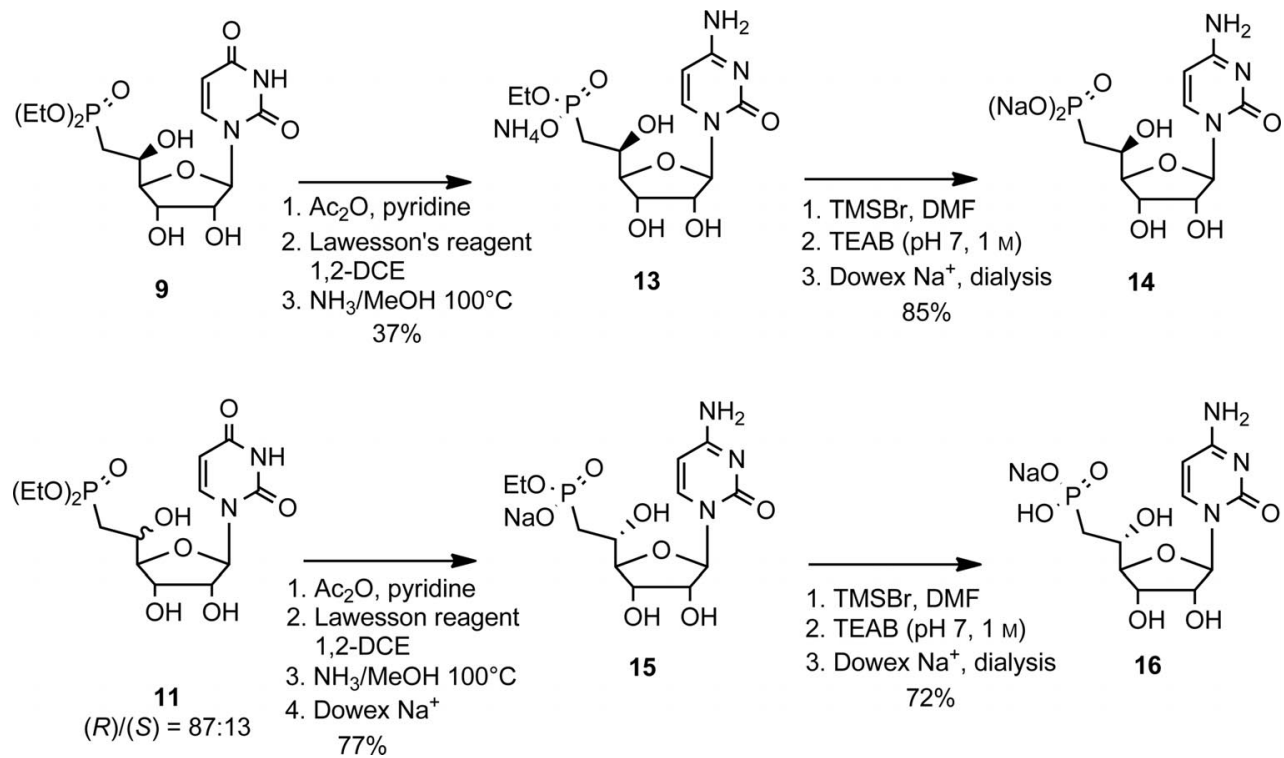

Scheme 5. Conversion of the uracil derivatives into the corresponding cytosine analogues $\mathbf{1 4}$ and $\mathbf{1 6 .}$

location results from the combination of the electronegative densities borne by the three oxygen atoms (C-5' keto group, $\mathrm{C}-2$ of the pyrimidine and the sugar). According to the spatial distribution of the electrostatic potential (Figure 1, C and D), the cerium ion occupies an important space in terms of charge density and therefore may prevent approach of the hydride from the back. In contrast, without any cerium, the nucleotide adopts an anti conformation and the $\mathrm{C}-5^{\prime}$ keto group is pushed to the front, giving enough space for hydride attack from the back side.

Then, a similar reaction sequence was applied to diethyl $\beta$-ketophosphonate derivative 7 to compare directly with our previous data ${ }^{[3]}$ and to allow access to $\beta$ - $(S)$-hydroxyphosphonate 10 and $\beta-(R)$-diastereoisomer 12, a hitherto unknown compound (Scheme 4). Briefly, intermediate 7 was reduced under classical conditions (Table 2, Entry 2) and by using Luche conditions (Table 2, Entry 6). Two batches of compound $\mathbf{8}$ with different ratios of the $(R)$ and $(S)$ isomers were obtained. Chromatographic separation of the two isomers was not possible at this stage, but was partially accomplished by using reverse-phase chromatography after removal of the various protecting groups. ${ }^{[13]}$ Thus, $(S)$ isomer 10 (pure compound) and desired $(R)$-isomer 12 (albeit contaminated with $9 \%$ of the other diastereoisomer) were isolated in good yield.

Starting from uracil intermediates 9 and 11, we then envisaged the synthesis of the corresponding derivatives in the cytosine series (Scheme 5). Many assays were performed to convert uracil into cytosine by using previously published procedures such as the method of Sung ${ }^{[14]}$ or through the formation of a nitrophenolic intermediate, ${ }^{[15]}$ but none of these attempts was successful. The only means to obtain expected derivatives $\mathbf{1 3}$ and $\mathbf{1 5}$ was to use Lawesson's reagent ${ }^{[16]}$ with prior acetylation of the free $2^{\prime}-, 3^{\prime}$-, and $5^{\prime}-$ hydroxy functions. After removal of the phosphonate protecting groups under standard conditions, diastereoisomers 14 and 16 were isolated.

\section{Conclusions}

We have developed a synthetic strategy to obtain both $(R)$ and $(S)$ diastereoisomers of nucleoside $\beta$-hydroxyphosphonate analogues in the uracil and cytosine series. This synthetic route requires fewer steps, gives better overall yields, and allows access to the $(R)$ isomer, which was not accessible using the previously described approach. On the basis of the study of the key step of the synthetic pathway (reduction of the $\beta$-ketophosphonate intermediate), a rationale for the diastereomeric ratio observed was proposed and was supported by modeling evidence.

\section{Experimental Section}

General: Unless otherwise stated, ${ }^{1} \mathrm{H}$ NMR spectra were recorded at $300 \mathrm{MHz}$ and ${ }^{13} \mathrm{C} \mathrm{NMR}$ spectra at $75 \mathrm{MHz}$ with proton decoupling at ambient temperature. Chemical shifts are given in $\delta$ values referring to the residual solvent peak $\left(\mathrm{CHCl}_{3}\right.$ at $\delta=7.26 \mathrm{ppm}$ and $77 \mathrm{ppm}$ or $\left[\mathrm{D}_{5}\right] \mathrm{DMSO}$ at $\delta=2.49 \mathrm{ppm}$ and $39.5 \mathrm{ppm}$ ) relative to TMS. Deuterium exchange, decoupling, and COSY experiments were performed to confirm proton assignments. $2 \mathrm{D}{ }^{1} \mathrm{H},{ }^{13} \mathrm{C}$ heteronuclear COSY were used for ${ }^{13} \mathrm{C}$ signal attributions. Unless otherwise stated, ${ }^{31} \mathrm{P}$ NMR spectra were recorded at ambient temperature at $121 \mathrm{MHz}$ with proton decoupling. Chemical shifts $\delta$ are reported relative to external $\mathrm{H}_{3} \mathrm{PO}_{4}$. ESI-QTof and FAB mass spectra were recorded in the positive-ion or negative-ion modes, using thioglycerol and glycerol mixture $(1: 1, \mathrm{v} / \mathrm{v}, \mathrm{GT})$ as matrix for FAB experiments. TLC was performed on precoated aluminum sheets of silica gel $60 \mathrm{~F}_{254}$, visualization of products being accomplished by UV absorbance followed by charring with a 5\% sulfuric acid solution in ethanol and then heating for carbohydrates and nucleotides. Flash chromatography was carried out using 63-100 $\mu \mathrm{m}$ silica gel or $40-63 \mu \mathrm{m}$ silica gel. Thin-layer chromatography was carried out using aluminum supported silica gel 60 plates. Solvents were reagent grade or purified/dried by distillation prior to use, solids were dried with $\mathrm{P}_{2} \mathrm{O}_{5}$ under reduced pressure at room temperature. Moisture-sensitive reactions were performed under an argon atmosphere using oven-dried glassware. All aqueous (aq.) solutions were 
saturated with the specified salt unless otherwise indicated. Organic solutions were dried with $\mathrm{Na}_{2} \mathrm{SO}_{4}$ after workup and solvents were removed by evaporation at reduced pressure.

Typical Procedure for the Synthesis of $\beta$-Ketophosphonate Derivatives (Method A): To a solution of dimethyl or diethyl methylphosphonate ( 2.5 equiv.) in dry $\mathrm{THF}(2.2 \mathrm{~mL} / \mathrm{mmol})$ at $-78^{\circ} \mathrm{C}$ under an argon atmosphere was dropwise added $n \mathrm{BuLi}(2 \mathrm{M}$ in pentane, 2.5 equiv.). After $30 \mathrm{~min}$ stirring at $-78^{\circ} \mathrm{C}$, a solution of the required ester ( 1 equiv.) at $-78^{\circ} \mathrm{C}$ in dry THF $(3.6 \mathrm{~mL} / \mathrm{mmol})$ was added. After $5 \mathrm{~h}$ stirring at $-78^{\circ} \mathrm{C}$, the reaction was quenched by addition of an aq. solution of $\mathrm{NH}_{4} \mathrm{Cl}$ and diluted with $\mathrm{CH}_{2} \mathrm{Cl}_{2}$. The organic layer was separated, and the aqueous layer was extracted with $\mathrm{CH}_{2} \mathrm{Cl}_{2}$. The organic layers were combined, dried with $\mathrm{Na}_{2} \mathrm{SO}_{4}$, filtered and concentrated. The crude product was purified by silica gel column chromatography.

Typical Procedure for Final Deprotection of the Phosphonate Derivatives (Method B): The protected phosphonate derivative (1 equiv.) was dissolved in anhydrous DMF $(20 \mathrm{~mL} / \mathrm{mmol})$ and trimethylsilyl bromide ( 15 equiv.) was added at $0{ }^{\circ} \mathrm{C}$. The mixture was stirred at room temperature until completion of the reaction (TLC). The reaction mixture was neutralized with an aq. triethylammonium hydrogen carbonate solution $(1 \mathrm{M}, \mathrm{pH} 7)$ and concentrated to dryness under high vacuum. Reverse-phase column chromatography of the crude materials, using water as eluent, gave rise to the corresponding phosphonic acid. The desired compound was obtained after ion exchange on DOWEX 50WX2 ( $\mathrm{Na}^{+}$form), dialysis and freeze-drying.

Benzyl-2-Phenylacetate (1): To an ice-cooled solution of benzyl alcohol $(10 \mathrm{~mL}, 96.6 \mathrm{mmol})$ in dry $\mathrm{CH}_{2} \mathrm{Cl}_{2}(450 \mathrm{~mL})$ was added dry $\mathrm{Et}_{3} \mathrm{~N}(14.94 \mathrm{~mL}, 106.3 \mathrm{mmol})$ and then benzoyl chloride (14.06 $\mathrm{mL}, 106.3 \mathrm{mmol})$. After $30 \mathrm{~min}$ stirring at $0{ }^{\circ} \mathrm{C}$, the reaction mixture was allowed to reach room temperature and then stirred for $2 \mathrm{~h}$. Then it was washed successively with aq. solution of $\mathrm{NaHCO}_{3}$ and water. The organic layers were dried with $\mathrm{Na}_{2} \mathrm{SO}_{4}$, filtered, and concentrated. The crude was purified by silica gel column chromatography $\left(\mathrm{CH}_{2} \mathrm{Cl}_{2}\right.$ to $\left.\mathrm{CH}_{2} \mathrm{Cl}_{2} / \mathrm{EtOAc}, 1: 1\right)$ to give $\mathbf{1}$ as a yellow oil (21.83 g, quantitative). $R_{\mathrm{f}}\left(\mathrm{CH}_{2} \mathrm{Cl}_{2} / \mathrm{EtOAc}, 1: 1\right)=0.73$. ${ }^{1} \mathrm{H}$ NMR (200 MHz, $\mathrm{CDCl}_{3}$ ): $\delta=7.40-7.20$ (m, $10 \mathrm{H}, \mathrm{H}-\mathrm{Ar}$ ), 5.15 (s, $2 \mathrm{H}, 1-\mathrm{H}), 3.76$ (s, $2 \mathrm{H}, 4-\mathrm{H}) \mathrm{ppm}$.

Dimethyl 2-Oxo-3-phenylpropylphosphonate (2): ${ }^{[17]}$ Compound 1 $(0.50 \mathrm{~g}, 2.21 \mathrm{mmol})$ was treated following method A. Purification by column chromatography of the crude materials on silica gel (hexane/ $\mathrm{CH}_{2} \mathrm{Cl}_{2}, 1: 1$, to $\mathrm{CH}_{2} \mathrm{Cl}_{2}$; then $\mathrm{CH}_{2} \mathrm{Cl}_{2}$ to EtOAc) gave compound 2 as a yellow liquid $(0.32 \mathrm{~g}, 60 \%)$ and $37 \%$ of the starting material was recovered $(0.187 \mathrm{~g}) . R_{\mathrm{f}}\left(\mathrm{CH}_{2} \mathrm{Cl}_{2} / \mathrm{EtOAc}, 1: 1\right)=$ 0.22. ${ }^{1} \mathrm{H}$ NMR $\left(200 \mathrm{MHz}, \mathrm{CDCl}_{3}\right): \delta=7.40-7.18$ (m, $\left.5 \mathrm{H}, \mathrm{H}-\mathrm{Ar}\right)$, $3.88(\mathrm{~s}, 2 \mathrm{H}, 3-\mathrm{H}), 3.78,3.74\left(2 \mathrm{~s}, 6 \mathrm{H}, \mathrm{OCH}_{3}\right), 3.15(\mathrm{~s}, 1 \mathrm{H}, 1-$ $\mathrm{H}), 3.05$ (s, $\left.1 \mathrm{H}, 11^{\prime}-\mathrm{H}\right)$ ppm. ${ }^{31} \mathrm{P}$ NMR $\left(81 \mathrm{MHz}, \mathrm{CDCl}_{3}\right): \delta=$ $23.6 \mathrm{ppm}$.

$\mathbf{2}^{\prime}, \mathbf{3}^{\prime}$ - $\boldsymbol{O}$-Isopropylidene Uridine (3): ${ }^{[18]}$ To a suspension of uridine $(12 \mathrm{~g}, 49 \mathrm{mmol})$ in acetone was added 2,2-dimethoxypropane $(18 \mathrm{~mL}, 148 \mathrm{mmol})$ and para-toluenesulfonic acid monohydrate (APTS, $0.94 \mathrm{~g}, 4.9 \mathrm{mmol}$ ). The mixture was stirred for $2 \mathrm{~h}$ at $60{ }^{\circ} \mathrm{C}$. The solution was evaporated under reduced pressure; the residue was dissolved in EtOAc and washed with an aq. $\mathrm{NaHCO}_{3}$ solution. The organic layer was dried with anhydrous $\mathrm{Na}_{2} \mathrm{SO}_{4}$, filtered, and evaporated under reduced pressure. The resulting solid was crystallized in acetone to get white crystals of compound $3(11.3 \mathrm{~g}$, 81\%). $R_{\mathrm{f}}\left(\mathrm{CH}_{2} \mathrm{Cl}_{2} / \mathrm{MeOH}, 9: 1\right)=0.4 .{ }^{1} \mathrm{H} \mathrm{NMR}\left(300 \mathrm{MHz},\left[\mathrm{D}_{6}\right]-\right.$ DMSO): $\delta=11.40$ (br. s, $1 \mathrm{H}$ exchangeable, NH), 7.79 (d, $J=$
$8.1 \mathrm{~Hz}, 1 \mathrm{H}, 6-\mathrm{H}), 5.83$ (d, $\left.J=2.4 \mathrm{~Hz}, 1 \mathrm{H}, 1^{\prime}-\mathrm{H}\right), 5.63$ (d, $J=$ $8.0 \mathrm{~Hz}, 1 \mathrm{H}, 5-\mathrm{H}), 5.12$ (br. s, $1 \mathrm{H}$ exchangeable, 5'-OH), 4.89 (dd, $\left.J=2.5,6.2 \mathrm{~Hz}, 1 \mathrm{H}, 2^{\prime}-\mathrm{H}\right), 4.74\left(\mathrm{dd}, J=3.6,6.2 \mathrm{~Hz}, 1 \mathrm{H}, 3^{\prime}-\mathrm{H}\right)$, 4.07 (dd, $\left.J=4.0,8.1 \mathrm{~Hz}, 1 \mathrm{H}, 4^{\prime}-\mathrm{H}\right), 3.57$ (br. s, $2 \mathrm{H}, 5^{\prime}-\mathrm{H}, 5^{\prime \prime}-\mathrm{H}$ ), $1.48,1.29\left[2 \mathrm{~s}, 6 \mathrm{H}, \mathrm{C}\left(\mathrm{CH}_{3}\right)_{2}\right] \mathrm{ppm} .{ }^{13} \mathrm{C} \mathrm{NMR}\left(75 \mathrm{MHz},\left[\mathrm{D}_{6}\right]-\right.$ DMSO): $\delta=163.2(\mathrm{C}-4), 150.3(\mathrm{C}-2), 141.8$ (C-6), 112.9 $\left[C\left(\mathrm{CH}_{3}\right)_{2}\right], 101.7(\mathrm{C}-5), 91.1\left(\mathrm{C}-1^{\prime}\right), 86.5\left(\mathrm{C}-4^{\prime}\right), 83.6\left(\mathrm{C}-2^{\prime}\right), 80.4$ $\left(\mathrm{C}-3^{\prime}\right), 61.2\left(\mathrm{C}^{\prime} 5^{\prime}\right), 27.0,25.1\left[\mathrm{C}\left(\mathrm{CH}_{3}\right)_{2}\right] \mathrm{ppm}$. MS $\left(\mathrm{FAB}^{+}\right): \mathrm{m} / \mathrm{z}=$ $113[\mathrm{~B}+2 \mathrm{H}]^{+}, 285[\mathrm{M}+\mathrm{H}]^{+}, 569[2 \mathrm{M}+\mathrm{H}]^{+}$. MS $\left(\mathrm{FAB}^{-}\right): m / z=$ $284[\mathrm{M}-\mathrm{H}]^{-}, 567[2 \mathrm{M}-\mathrm{H}]^{-}$.

$2^{\prime}, 3^{\prime}$-O-Isopropylideneuridine-5' -carboxylic Acid (4): ${ }^{[7]}$ In a flask protected from day light was introduced BAIB [(diacetoxyiodo)benzene] (3.74 g, $11.62 \mathrm{mmol})$, TEMPO (165 mg, $1.06 \mathrm{mmol})$, and $3(1.5 \mathrm{~g}, 5.28 \mathrm{mmol})$. Water/acetonitrile $(1: 1,12 \mathrm{~mL})$ was added, and the reaction mixture was stirred at $45^{\circ} \mathrm{C}$ for $5 \mathrm{~h}$. Then, the reaction mixture was concentrated under reduced pressure, diluted with a minimum of $\mathrm{Et}_{2} \mathrm{O}$, triturated, and filtered to give $\mathbf{4}$ as a white powder without further purification $(1.27 \mathrm{~g}, 81 \%)$. $R_{\mathrm{f}}($ EtOAc $)=$ 0.10. $[\alpha]_{\mathrm{D}}^{20}=-20.3(c=0.59, \mathrm{MeOH})$. UV/Vis $(95 \% \mathrm{EtOH}): \lambda_{\max }$ $\left(\varepsilon, \mathrm{dm}^{3} \mathrm{~mol}^{-1} \mathrm{~cm}^{-1}\right)=261(9700), 229(1900) \mathrm{nm} .{ }^{1} \mathrm{H}$ NMR (400 MHz, [D $\mathrm{D}_{6}$ DMSO): $\delta=11.35$ (br. s, $\left.1 \mathrm{H}, \mathrm{NH}\right), 7.82$ (d, $J=$ $8.4 \mathrm{~Hz}, 1 \mathrm{H}, 6-\mathrm{H}), 5.78$ (s, $\left.1 \mathrm{H}, 1^{\prime}-\mathrm{H}\right), 5.63$ (d, $J=8.0 \mathrm{~Hz}, 1 \mathrm{H}, 5-$ $\mathrm{H}), 5.20\left(\mathrm{~m}, 2 \mathrm{H}, 2^{\prime}-\mathrm{H}, 3^{\prime}-\mathrm{H}\right), 4.57\left(\mathrm{~d}, J=2.0 \mathrm{~Hz}, 1 \mathrm{H}, 4^{\prime}-\mathrm{H}\right), 1.47$, $1.31\left[2 \mathrm{~s}, 12 \mathrm{H}, \mathrm{C}\left(\mathrm{CH}_{3}\right)_{2}\right]$ ppm. ${ }^{13} \mathrm{C} \mathrm{NMR}\left(100 \mathrm{MHz},\left[\mathrm{D}_{6}\right]-\right.$ DMSO): $\delta=171.4$ (C-5'), 164.0 (C-4), 151.3 (C-2), 145.3 (C-6),

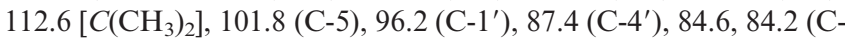
$\left.2^{\prime}, \mathrm{C}-3^{\prime}\right), 26.9,25.2\left[\mathrm{C}\left(\mathrm{CH}_{3}\right)_{2}\right] \mathrm{ppm} . \mathrm{MS}\left(\mathrm{ESI}^{+}\right): \mathrm{m} / \mathrm{z}=299[\mathrm{M}+$ $\mathrm{H}]^{+}, 597[2 \mathrm{M}+\mathrm{H}]^{+}, 895[3 \mathrm{M}+\mathrm{H}]^{+} . \mathrm{MS}\left(\mathrm{ESI}^{-}\right): m / z=297[\mathrm{M}-$ $\mathrm{H}^{-}, 595[2 \mathrm{M}-\mathrm{H}]^{-}$. HRMS $\left(\mathrm{ESI}^{+}\right)$: calcd. for $\mathrm{C}_{12} \mathrm{H}_{15} \mathrm{~N}_{2} \mathrm{O}_{7}[\mathrm{M}+$ $\mathrm{H}]^{+}$299.0879; found 299.0880.

$\mathbf{2}^{\prime}, \mathbf{3}^{\prime}$ - $\boldsymbol{O}$-Isopropylideneuridine-5' -benzyl Ester (5): To a suspension of carboxylic acid $4(1.27 \mathrm{~g}, 4.26 \mathrm{mmol})$ in acetonitrile $(30 \mathrm{~mL})$ was added DCC (0.88 g, $4.26 \mathrm{mmol}), 4$-DMAP (57 mg, $0.43 \mathrm{mmol}$ ), and benzyl alcohol $(0.44 \mathrm{~mL}, 4.26 \mathrm{mmol})$. The reaction mixture was stirred overnight at $45-50^{\circ} \mathrm{C}$. Then, another addition of DCC and benzyl alcohol (2.13 mmol of each) and 4-DMAP (0.22 mmol) was performed, and the solution was stirred $5 \mathrm{~h}$ more at $45-50{ }^{\circ} \mathrm{C}$. Acetonitrile was then evaporated under reduced pressure; the reaction mixture was diluted in a minimum of $\mathrm{CH}_{2} \mathrm{Cl}_{2}$ and filtered. The crude material was purified by silica gel column chromatography $\left(\mathrm{CH}_{2} \mathrm{Cl}_{2}\right.$ to $\mathrm{CH}_{2} \mathrm{Cl}_{2} / \mathrm{EtOAc}$, 65:35) to give a white foam that was diluted in a minimum of $\mathrm{CH}_{2} \mathrm{Cl}_{2}$ and filtered again to give $\mathbf{5}$ as a white foam $(1.61 \mathrm{~g}, 98 \%) . R_{\mathrm{f}}($ EtOAc $)=0.44 \cdot[\alpha]_{\mathrm{D}}^{20}=-9.3(c=$ 0.485, MeOH). $\mathrm{C}_{19} \mathrm{H}_{20} \mathrm{~N}_{2} \mathrm{O}_{7}$ (388.13): calcd. C 58.76, $\mathrm{H} 5.19, \mathrm{~N}$ 7.21; found C 58.75, H 5.30, N 7.26. UV/Vis $(95 \% \mathrm{EtOH}): \lambda_{\max }(\varepsilon$, $\left.\mathrm{dm}^{3} \mathrm{~mol}^{-1} \mathrm{~cm}^{-1}\right)=257$ (9200), $229(2200) \mathrm{nm} .{ }^{1} \mathrm{H}$ NMR $(300 \mathrm{MHz}$, [D $]$ DMSO): $\delta=11.43$ (br. s, $1 \mathrm{H}, \mathrm{NH}), 7.80$ (d, $J=8.03 \mathrm{~Hz}, 1 \mathrm{H}$, 6-H), 7.35 (m, 5 H, H-Ar), 5.77 (s, $\left.1 \mathrm{H}, 1^{\prime}-\mathrm{H}\right), 5.61$ (d, $J=7.93 \mathrm{~Hz}$, $1 \mathrm{H}, 5-\mathrm{H}), 5.29\left(\mathrm{dd}, J=1.28,6.09 \mathrm{~Hz}, 1 \mathrm{H}, 3^{\prime}-\mathrm{H}\right), 5.24(\mathrm{dd}, J=$ $\left.6.07 \mathrm{~Hz}, 1 \mathrm{H}, 2^{\prime}-\mathrm{H}\right), 5.09$ (d, $\left.J=12.34 \mathrm{~Hz}, 1 \mathrm{H}, \mathrm{CH}_{2}\right), 4.98(\mathrm{~d}, J=$ $\left.12.34 \mathrm{~Hz}, 1 \mathrm{H}, \mathrm{CH}_{2}\right), 4.78\left(\mathrm{~d}, J=1.10 \mathrm{~Hz}, 1 \mathrm{H}, 4^{\prime}-\mathrm{H}\right), 1.45,1.31$ [2 s, $\left.6 \mathrm{H}, \mathrm{C}\left(\mathrm{CH}_{3}\right)_{2}\right] \mathrm{ppm} .{ }^{13} \mathrm{C} \mathrm{NMR}\left(75 \mathrm{MHz},\left[\mathrm{D}_{6}\right] \mathrm{DMSO}\right): \delta=169.3$ (C-5'), 163.3 (C-4), 151.1 (C-2), 145.1 (C-6), 135.4, 128.4, 128.1 (C-

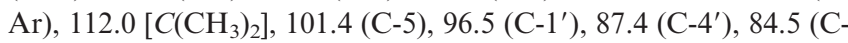
$\left.2^{\prime}\right), 83.8\left(\mathrm{C}-3^{\prime}\right), 66.2\left(\mathrm{C}-6^{\prime}\right), 26.3,24.6\left[\mathrm{C}\left(\mathrm{CH}_{3}\right)_{2}\right] \mathrm{ppm} . \mathrm{MS}\left(\mathrm{ESI}^{+}\right)$: $m / z=389[\mathrm{M}+\mathrm{H}]^{+}, 777[2 \mathrm{M}+\mathrm{H}]^{+} . \mathrm{MS}\left(\mathrm{ESI}^{-}\right): m / z=387[\mathrm{M}-$ $\mathrm{H}]^{-}$. HRMS $\left(\mathrm{ESI}^{+}\right.$): calcd. for $\mathrm{C}_{19} \mathrm{H}_{21} \mathrm{~N}_{2} \mathrm{O}_{7}[\mathrm{M}+\mathrm{H}]^{+}$389.1349; found 389.1354 .

1-(6' -Deoxy-6' -dimethylphosphono-2', $3^{\prime}$ - $O$-isopropylidene-5' -oxo- $\beta$ D-ribohexofuranosyl)uracil (6): Compound 5 (1.162 g, $2.99 \mathrm{mmol})$ was treated with method A. Column chromatography of the crude materials on silica gel $\left(\mathrm{CH}_{2} \mathrm{Cl}_{2}\right.$ to EtOAc) gave $\mathbf{6}$ as a white foam 
$(0.75 \mathrm{~g}, 62 \%) . R_{\mathrm{f}}\left(\mathrm{CH}_{2} \mathrm{Cl}_{2} /\right.$ acetone, $\left.1: 2\right)=0.26 .[\alpha]_{\mathrm{D}}^{20}=-37.8(c=$ $0.555, \mathrm{MeOH}) . \mathrm{UV} / \mathrm{Vis}(95 \% \mathrm{EtOH}): \lambda_{\max }\left(\varepsilon, \mathrm{dm}^{3} \mathrm{~mol}^{-1} \mathrm{~cm}^{-1}\right)=$ 257 (9600), 229 (2800) nm. $\mathrm{C}_{15} \mathrm{H}_{21} \mathrm{~N}_{2} \mathrm{O}_{9} \mathrm{P}$ (404.09): calcd. C 44.56, $\mathrm{H}$ 5.24, N 6.93; found $\mathrm{C} 43.89, \mathrm{H} 5.78, \mathrm{~N}$ 6.73. ${ }^{1} \mathrm{H} \mathrm{NMR}$ (300 MHz, [D $\mathrm{D}_{6}$ DMSO): $\delta=11.50$ (br. s, $1 \mathrm{H}$ exchangeable, $\mathrm{NH}$ ), $7.91(\mathrm{~d}, J=7.99 \mathrm{~Hz}, 1 \mathrm{H}, 6-\mathrm{H}), 5.90\left(\mathrm{~s}, 1 \mathrm{H}, 1^{\prime}-\mathrm{H}\right), 5.71(\mathrm{~d}, J=$ $7.94 \mathrm{~Hz}, 1 \mathrm{H}, 5-\mathrm{H}), 5.16$ (m, $\left.2 \mathrm{H}, 2^{\prime}-\mathrm{H}, 3^{\prime}-\mathrm{H}\right), 4.53$ (d, $J=1.06 \mathrm{~Hz}$, $\left.1 \mathrm{H}, 4^{\prime}-\mathrm{H}\right), 3.71\left(\mathrm{~m}, 6 \mathrm{H}, \mathrm{OCH}_{3}\right), 3.57(\mathrm{dd}, J=14.23,21.55 \mathrm{~Hz}, 1$ $\left.\mathrm{H}, 6^{\prime}-\mathrm{H}\right), 2.93\left(\mathrm{dd}, J=14.23,22.21 \mathrm{~Hz}, 1 \mathrm{H}, 6^{\prime}-\mathrm{H}^{\prime}\right), 1.53,1.37$ [2 s, $6 \mathrm{H}, \mathrm{C}\left(\mathrm{CH}_{3}\right)_{2}$ ] ppm. ${ }^{1} \mathrm{H}$ NMR $\left(300 \mathrm{MHz}, \mathrm{CDCl}_{3}\right): \delta=9.63$ (br. s, $1 \mathrm{H}$ exchangeable, NH), 7.27 (d, $J=8.06 \mathrm{~Hz}, 1 \mathrm{H}, 6-\mathrm{H}), 5.69$ (d, $J=7.97 \mathrm{~Hz}, 1 \mathrm{H}, 5-\mathrm{H}), 5.50\left(\mathrm{~s}, 1 \mathrm{H}, 1^{\prime}-\mathrm{H}\right), 5.23\left(\mathrm{~m}, 1 \mathrm{H}, 3^{\prime}-\mathrm{H}\right)$, $4.96\left(\mathrm{~d}, J=6.37 \mathrm{~Hz}, 1 \mathrm{H}, 2^{\prime}-\mathrm{H}\right), 4.62\left(\mathrm{~d}, J=1.87 \mathrm{~Hz}, 1 \mathrm{H}, 4^{\prime}-\mathrm{H}\right)$, $3.73\left(\mathrm{~m}, 6 \mathrm{H}, \mathrm{OCH}_{3}\right), 3.40\left(\mathrm{dd}, J=13.82,22.55 \mathrm{~Hz}, 1 \mathrm{H}, 6^{\prime}-\mathrm{H}\right)$, $2.93\left(\mathrm{dd}, J=13.78,22.83 \mathrm{~Hz}, 1 \mathrm{H}, 6^{\prime}-\mathrm{H}^{\prime}\right), 1.48,1.29[2 \mathrm{~s}, 6 \mathrm{H}$, $\left.\mathrm{C}\left(\mathrm{CH}_{3}\right)_{2}\right] \mathrm{ppm} .{ }^{13} \mathrm{C} \mathrm{NMR}\left(75 \mathrm{MHz},\left[\mathrm{D}_{6}\right] \mathrm{DMSO}\right): \delta=199.8$ (d, $J$ $\left.=6.04 \mathrm{~Hz}, \mathrm{C}-5^{\prime}\right), 163.4$ (C-4), 151.0 (C-2), 144.6 (C-6), 112.3 [C $\left.\left(\mathrm{CH}_{3}\right)_{2}\right], 101.7(\mathrm{C}-5), 96.7\left(\mathrm{C}-1^{\prime}\right), 93.5\left(\mathrm{C}-4^{\prime}\right), 84.2,83.0\left(\mathrm{C}-2^{\prime}\right.$, C-3'), $52.6\left(2 \mathrm{~d}, J=6.04 \mathrm{~Hz}, \mathrm{OCH}_{3}\right), 35.2\left(\mathrm{C}-6^{\prime}\right), 26.3,24.7$ $\left[\mathrm{C}\left(\mathrm{CH}_{3}\right)_{2}\right] \mathrm{ppm} .{ }^{31} \mathrm{P}$ NMR $\left(121 \mathrm{MHz},\left[\mathrm{D}_{6}\right] \mathrm{DMSO}\right): \delta=22.6 \mathrm{ppm}$. $\mathrm{MS}\left(\mathrm{ESI}^{+}\right): m / z=405[\mathrm{M}+\mathrm{H}]^{+}, 809[2 \mathrm{M}+\mathrm{H}]^{+}$. $\mathrm{MS}\left(\mathrm{ESI}^{-}\right): m / z$ $=403[\mathrm{M}-\mathrm{H}]^{-}, 807[2 \mathrm{M}-\mathrm{H}]^{-}$. HRMS: calcd. for $\mathrm{C}_{15} \mathrm{H}_{22} \mathrm{~N}_{2} \mathrm{O}_{9} \mathrm{P}$ $[\mathrm{M}+\mathrm{H}]^{+}$405.1063; found 405.1064.

1-(6'-Deoxy-6' -diethylphosphono-2', $3^{\prime}$ - $O$-isopropylidene-5' -oxo- $\beta$ D-ribohexofuranosyl)uracil (7): Compound 5 (0.50 g, $1.29 \mathrm{mmol})$ was treated with method A. Eluent: $\mathrm{CH}_{2} \mathrm{Cl}_{2} /$ EtOAc (1:1) to EtOAc/ $\mathrm{MeOH}$ (9:1). Compound 7 was obtained as a white foam (254 mg, $46 \%) . R_{\mathrm{f}}\left(\mathrm{CH}_{2} \mathrm{Cl}_{2} / \mathrm{MeOH}, 95: 5\right)=0.4 .[\alpha]_{\mathrm{D}}^{20}=-32.7(c=1.00$, $\mathrm{MeOH})$. UV/Vis $(95 \% \mathrm{EtOH}): \lambda_{\max }\left(\varepsilon, \mathrm{dm}^{3} \mathrm{~mol}^{-1} \mathrm{~cm}^{-1}\right)=256$ (10100), 231 (2900) nm. ${ }^{1} \mathrm{H}$ NMR (300 MHz, [D 6 DMSO): $\delta=$ 11.45 (br. s, $1 \mathrm{H}$ exchangeable, NH), 7.87 (d, $J=7.9 \mathrm{~Hz}, 1 \mathrm{H}, 6-$ H), $5.85\left(\mathrm{~d}, J=2.4 \mathrm{~Hz}, 1 \mathrm{H}, 1^{\prime}-\mathrm{H}\right), 5.56(\mathrm{~d}, J=7.9 \mathrm{~Hz}, 1 \mathrm{H}, 5-\mathrm{H})$, $5.1\left(\mathrm{~m}, 2 \mathrm{H}, 2^{\prime}-\mathrm{H}, 3^{\prime}-\mathrm{H}\right), 4.50\left(\mathrm{~d}, J=1.5 \mathrm{~Hz}, 1 \mathrm{H}, 4^{\prime}-\mathrm{H}\right), 3.80(\mathrm{~m}$, $\left.4 \mathrm{H}, \mathrm{OCH}_{2} \mathrm{CH}_{3}\right), 3.49$ (dd, $\left.J=16.2 \mathrm{~Hz}, 1 \mathrm{H}, 6^{\prime}-\mathrm{H}\right), 2.83$ (dd, $J=$ $\left.16.2 \mathrm{~Hz}, 1 \mathrm{H}, 6^{\prime \prime}-\mathrm{H}\right), 1.50,1.30\left[2 \mathrm{~s}, 6 \mathrm{H}, \mathrm{C}\left(\mathrm{CH}_{3}\right)_{2}\right], 1.23(\mathrm{t}, J=$ $\left.7.0 \mathrm{~Hz}, 6 \mathrm{H}, \mathrm{OCH}_{2} \mathrm{CH}_{3}\right) \mathrm{ppm} .{ }^{13} \mathrm{C} \mathrm{NMR}\left(75 \mathrm{MHz},\left[\mathrm{D}_{6}\right] \mathrm{DMSO}\right): \delta$ $=199.8\left(\mathrm{~d}, J=6.0 \mathrm{~Hz}, \mathrm{C}-5^{\prime}\right), 163.5(\mathrm{C}-4), 151.0(\mathrm{C}-2), 144.6(\mathrm{C}-$ 6), $112.4\left[C\left(\mathrm{CH}_{3}\right)_{2}\right], 101.7(\mathrm{C}-5), 96.7\left(\mathrm{C}-1^{\prime}\right), 93.5\left(\mathrm{C}-4^{\prime}\right), 84.2(\mathrm{C}-$ $\left.3^{\prime}\right), 83.0\left(\mathrm{C}-2^{\prime}\right), 61.9\left(2 \mathrm{~d}, J=6.0 \mathrm{~Hz}, \mathrm{OCH}_{2} \mathrm{CH}_{3}\right), 36.3(\mathrm{~d}, J=$ $\left.124.8 \mathrm{~Hz}, \mathrm{C}^{-6} 6^{\prime}\right), 26.4,24.7\left[\mathrm{C}\left(\mathrm{CH}_{3}\right)_{2}\right], 16.1,16.0\left(\mathrm{OCH}_{2} \mathrm{CH}_{3}\right) \mathrm{ppm}$. ${ }^{31} \mathrm{P}$ NMR (121 MHz, [D $]$ DMSO): $\delta=20.8 \mathrm{ppm}$. MS $\left(\mathrm{FAB}^{+}\right): \mathrm{m} / z$ $=433[\mathrm{M}+\mathrm{H}]^{+}, 865[2 \mathrm{M}+\mathrm{H}]^{+} . \mathrm{MS}\left(\mathrm{FAB}^{-}\right): m / z=111[\mathrm{~B}]^{-}, 431$ $[\mathrm{M}-\mathrm{H}]^{-}, 863[2 \mathrm{M}-\mathrm{H}]^{-}$.

1-[6' -Deoxy-6' -diethylphosphono-2' $\mathbf{3}^{\prime}$ - $O$-isopropylidene- $\beta$-D-ribo$\left(5^{\prime} R / S\right)$-hexofuranosyl]uracil (8)

Standard Conditions: To a solution of 7 (250 $\mathrm{mg}, 0.58 \mathrm{mmol})$ in dry $\mathrm{MeOH}(9 \mathrm{~mL})$ at $-50{ }^{\circ} \mathrm{C}$ under an argon atmosphere was added $\mathrm{NaBH}_{4}(87.6 \mathrm{mg}, 2.31 \mathrm{mmol})$. After stirring for $5 \mathrm{~h}$ at $-30^{\circ} \mathrm{C}$, the reaction was complete. The reaction mixture was neutralized with $1 \mathrm{~N} \mathrm{HCl}$, evaporated under reduced pressure, and co-evaporated twice with toluene. The crude was purified by column chromatography $\left(\mathrm{CH}_{2} \mathrm{Cl}_{2}\right.$ to acetone) to give 8 as a white foam [224 $\mathrm{mg}, 89 \%$, mixture of two diastereoisomers, $(S) /(R)=91: 9]$. An analytical sample of the pure $(S)$ isomer was obtained for spectral characterization. $R_{\mathrm{f}}\left(\mathrm{CH}_{2} \mathrm{Cl}_{2} / \mathrm{MeOH}, 9: 1\right)=0.4 .[a]_{\mathrm{D}}^{20}=-18.1(c=1.04$, $\mathrm{MeOH})$. UV/Vis $(95 \% \mathrm{EtOH}): \lambda_{\max }\left(\varepsilon, \mathrm{dm}^{3} \mathrm{~mol}^{-1} \mathrm{~cm}^{-1}\right)=258$ (10000), 228 (2000) nm. ${ }^{1} \mathrm{H}$ NMR (300 MHz, [D $]$ DMSO): $\delta=$ 11.40 (br. s, $1 \mathrm{H}$ exchangeable, $\mathrm{NH}), 7.78(\mathrm{~d}, J=8.0 \mathrm{~Hz}, 1 \mathrm{H}, 6-$ $\mathrm{H}), 5.83\left(\mathrm{~d}, J=2.4 \mathrm{~Hz}, 1 \mathrm{H}, 1^{\prime}-\mathrm{H}\right), 5.65(\mathrm{~d}, J=8.0 \mathrm{~Hz}, 1 \mathrm{H}, 5-\mathrm{H})$, $5.50\left(\mathrm{~d}, J=5.8 \mathrm{~Hz}, 1 \mathrm{H}\right.$ exchangeable, $\left.5^{\prime}-\mathrm{OH}\right), 4.9\left(\mathrm{~m}, 2 \mathrm{H}, 2^{\prime}-\mathrm{H}\right.$, $\left.3^{\prime}-\mathrm{H}\right), 3.80\left(\mathrm{~m}, 6 \mathrm{H}, \mathrm{OCH}_{2} \mathrm{CH}_{3}, 4^{\prime}-\mathrm{H}, 5^{\prime}-\mathrm{H}\right), 2.00-1.90(\mathrm{~m}, 2 \mathrm{H}$, $\left.6^{\prime}-\mathrm{H}, 6^{\prime \prime}-\mathrm{H}\right), 1.50,1.30\left[2 \mathrm{~s}, 6 \mathrm{H}, \mathrm{C}\left(\mathrm{CH}_{3}\right)_{2}\right], 1.23(\mathrm{t}, J=7.0 \mathrm{~Hz}, 6$
$\mathrm{H}, \mathrm{OCH}_{2} \mathrm{CH}_{3}$ ) ppm. ${ }^{1} \mathrm{H}$ NMR (200 MHz, $\mathrm{CDCl}_{3}$ ): $\delta=10.23$ (br. s, $1 \mathrm{H}$ exchangeable, NH), $7.54(\mathrm{~d}, J=8.05 \mathrm{~Hz}, 1 \mathrm{H}, 6-\mathrm{H}), 5.76(\mathrm{~d}$, $\left.J=2.75 \mathrm{~Hz}, 1 \mathrm{H}, 1^{\prime}-\mathrm{H}\right), 5.66(\mathrm{~d}, J=8.01 \mathrm{~Hz}, 1 \mathrm{H}, 5-\mathrm{H}), 4.89-4.70$ (m, $\left.2 \mathrm{H}, 2^{\prime}-\mathrm{H}, 3^{\prime}-\mathrm{H}\right), 4.35-3.99$ (m, $\left.6 \mathrm{H}, \mathrm{OCH}_{2} \mathrm{CH}_{3}, 4^{\prime}-\mathrm{H}, 5^{\prime}-\mathrm{H}\right)$, $2.11-1.81\left(\mathrm{~m}, 2 \mathrm{H}, 6^{\prime}-\mathrm{H}, 6^{\prime \prime}-\mathrm{H}\right), 1.52-1.20\left[\mathrm{~m}, 12 \mathrm{H}, \mathrm{C}\left(\mathrm{CH}_{3}\right)_{2}\right.$, $\mathrm{OCH}_{2} \mathrm{CH}_{3}$ ] ppm. ${ }^{13} \mathrm{C} \mathrm{NMR}\left(75 \mathrm{MHz},\left[\mathrm{D}_{6}\right] \mathrm{DMSO}\right): \delta=163.6(\mathrm{C}-$ 4), $150.8(\mathrm{C}-2), 142.8(\mathrm{C}-6), 113.5\left[\mathrm{C}\left(\mathrm{CH}_{3}\right)_{2}\right], 102.3(\mathrm{C}-5), 91.5(\mathrm{C}-$ $\left.1^{\prime}\right), 88.9\left(\mathrm{~d}, J=15.1 \mathrm{~Hz}, \mathrm{C}-4^{\prime}\right), 83.8\left(\mathrm{C}-2^{\prime}\right), 80.5\left(\mathrm{C}-3^{\prime}\right), 66.0(\mathrm{~d}, J$ $\left.=4.0 \mathrm{~Hz}, \mathrm{C}-5^{\prime}\right), 61.5\left(2 \mathrm{~d}, J=6.0 \mathrm{~Hz}, \mathrm{OCH}_{2} \mathrm{CH}_{3}\right), 30.3(\mathrm{~d}, J=$ $\left.138.7 \mathrm{~Hz}, \mathrm{C}-6^{\prime}\right), 27.5,25.7\left[\mathrm{C}\left(\mathrm{CH}_{3}\right)_{2}\right], 16.72,16.66\left(\mathrm{OCH}_{2} \mathrm{CH}_{3}\right)$ ppm. ${ }^{31} \mathrm{P}$ NMR $\left(121 \mathrm{MHz},\left[\mathrm{D}_{6}\right] \mathrm{DMSO}\right): \delta=30.3 \mathrm{ppm}$. MS $\left(\mathrm{FAB}^{+}\right): m / z=435[\mathrm{M}+\mathrm{H}]^{+}, 869[2 \mathrm{M}+\mathrm{H}]^{+}$. MS $\left(\mathrm{FAB}^{-}\right): m / z=$ $111[\mathrm{~B}]^{-}, 433[\mathrm{M}-\mathrm{H}]^{-}, 867[2 \mathrm{M}-\mathrm{H}]^{-}$

Luche Conditions: To a solution of $7(0.25 \mathrm{~g}, 0.58 \mathrm{mmol})$ in dry $\mathrm{MeOH}(4.3 \mathrm{~mL})$ at $-30{ }^{\circ} \mathrm{C}$ under an argon atmosphere was added $\mathrm{CeCl}_{3} \cdot 7 \mathrm{H}_{2} \mathrm{O}(181 \mathrm{mg}, 0.49 \mathrm{mmol})$ and $\mathrm{NaBH}_{4}(34 \mathrm{mg}, 0.90 \mathrm{mmol})$. After $3 \mathrm{~h}$ stirring at $-30{ }^{\circ} \mathrm{C}$, the reaction mixture was neutralized with $1 \mathrm{~N} \mathrm{HCl}$, evaporated under reduced pressure, and co-evaporated with toluene. The crude was purified by column chromatography $\left(\mathrm{CH}_{2} \mathrm{Cl}_{2}\right.$ to acetone) to give $\mathbf{8}$ as a mixture of the two diastereoisomers [215 mg, 86\%, $(S) /(R)=44: 56] . R_{\mathrm{f}}\left(\mathrm{CH}_{2} \mathrm{Cl}_{2} / \mathrm{MeOH}\right.$, 9:1) $=0.4 .{ }^{1} \mathrm{H}$ NMR $\left(200 \mathrm{MHz}, \mathrm{CDCl}_{3}\right): \delta=10.23$ (br. s, $1 \mathrm{H}$ exchangeable, NH), $7.72(\mathrm{~d}, J=8.11 \mathrm{~Hz}, 1 \mathrm{H}, 6-\mathrm{H}), 5.93$ (d, $J=$ $\left.3.60 \mathrm{~Hz}, 1 \mathrm{H}, 1^{\prime}-\mathrm{H}\right), 5.68(\mathrm{~d}, J=8.10 \mathrm{~Hz}, 1 \mathrm{H}, 5-\mathrm{H}), 4.89-4.70(\mathrm{~m}$, $\left.2 \mathrm{H}, 2^{\prime}-\mathrm{H}, 3^{\prime}-\mathrm{H}\right), 4.35-3.99$ (m, $\left.6 \mathrm{H}, \mathrm{OCH}_{2} \mathrm{CH}_{3}, 4^{\prime}-\mathrm{H}, 5^{\prime}-\mathrm{H}\right), 2.11-$ $1.81\left(\mathrm{~m}, 2 \mathrm{H}, 6^{\prime}-\mathrm{H}, 6^{\prime \prime}-\mathrm{H}\right), 1.52-1.20\left[\mathrm{~m}, 12 \mathrm{H}, \mathrm{C}\left(\mathrm{CH}_{3}\right)_{2}\right.$, $\mathrm{OCH}_{2} \mathrm{CH}_{3}$ ] ppm.

1-[6' -Deoxy-6' -diethylphosphono- $\beta$-D-ribo-(5' $S)$-hexofuranosyl]uracil (9): ${ }^{[3]}$ Protected $\beta$-hydroxyphosphonate $8(117 \mathrm{mg}$, $0.27 \mathrm{mmol}$ ) was dissolved in an aqueous solution of $70 \%$ trifluoroacetic acid $(2.15 \mathrm{~mL})$ at room temperature, and the mixture was stirred for $3 \mathrm{~h}$. The solution was evaporated under reduced pressure and co-evaporated with absolute ethanol. The crude material was purified by reverse-phase chromatography $\left(\mathrm{H}_{2} \mathrm{O} / \mathrm{MeOH} 0\right.$ to $\left.50 \%\right)$ to give 9 as a white foam (106 mg, 91\%). $R_{\mathrm{f}}\left(\mathrm{CH}_{2} \mathrm{Cl}_{2} / \mathrm{MeOH}, 9: 1\right)$ $=0.2 \cdot[\alpha]_{\mathrm{D}}^{20}=-5.8(c=1.04, \mathrm{MeOH}) . \mathrm{UV} / \mathrm{Vis}(95 \% \mathrm{EtOH}): \lambda_{\max }$ $\left(\varepsilon, \mathrm{dm}^{3} \mathrm{~mol}^{-1} \mathrm{~cm}^{-1}\right)=260$ (10000), 228 (2000) nm. $\mathrm{C}_{14} \mathrm{H}_{23} \mathrm{~N}_{2} \mathrm{O}_{9} \mathrm{P}$ (394.11): calcd. C 42.64, H 5.88, N 7.10; found C 42.53, H 6.14, $\mathrm{N}$ 7.03. ${ }^{1} \mathrm{H}$ NMR $\left(300 \mathrm{MHz},\left[\mathrm{D}_{6}\right] \mathrm{DMSO}\right): \delta=11.3$ (br. s, $1 \mathrm{H}$ exchangeable, NH), 7.80 (d, $J=8.1 \mathrm{~Hz}, 1 \mathrm{H}, 6-\mathrm{H}), 5.78$ (d, $J=$ $\left.6.4 \mathrm{~Hz}, 1 \mathrm{H}, 1^{\prime}-\mathrm{H}\right), 5.63(\mathrm{~d}, J=8.1 \mathrm{~Hz}, 1 \mathrm{H}, 5-\mathrm{H}), 5.50$ (d, $J=$ $5.0 \mathrm{~Hz}, 1 \mathrm{H}$ exchangeable, 5'-OH), 5.36 (br. s, $1 \mathrm{H}$ exchangeable, 2'-OH), 5.10 (br. s, $1 \mathrm{H}$ exchangeable, 3'-OH), 4.1-3.9 (m, $7 \mathrm{H}, 3^{\prime}$ $\left.\mathrm{H}, 2^{\prime}-\mathrm{H}, 5^{\prime}-\mathrm{H}, \mathrm{OCH}_{2} \mathrm{CH}_{3}\right), 3.80\left(\mathrm{t}, J=3.0 \mathrm{~Hz}, 1 \mathrm{H}, 4^{\prime}-\mathrm{H}\right), 2.10$ $1.80\left(\mathrm{~m}, 2 \mathrm{H}, 6^{\prime}-\mathrm{H}, 6^{\prime \prime}-\mathrm{H}\right), 1.23\left(\mathrm{t}, J=7.0 \mathrm{~Hz}, 6 \mathrm{H}, \mathrm{OCH}_{2} \mathrm{CH}_{3}\right)$ ppm. ${ }^{13} \mathrm{C}$ NMR (75 MHz, [D $]$ DMSO): $\delta=163.0$ (C-4), 150.8 (C2), 140.9 (C-6), 101.9 (C-5), 87.3 (d, $J=14.3 \mathrm{~Hz}, \mathrm{C}-4^{\prime}$ ), 86.9 (C$\left.1^{\prime}\right), 73.1\left(\mathrm{C}-2^{\prime}\right), 68.5\left(\mathrm{C}-3^{\prime}\right), 65.6\left(\mathrm{~d}, J=3.0 \mathrm{~Hz}, \mathrm{C}-5^{\prime}\right), 61.1,60.8$ $\left(2 \mathrm{~d}, J=6.0 \mathrm{~Hz}, \mathrm{OCH}_{2} \mathrm{CH}_{3}\right), 29.5$ (d, $\left.J=137.3 \mathrm{~Hz}, \mathrm{C}-6^{\prime}\right), 16.2$, $16.1\left(\mathrm{OCH}_{2} \mathrm{CH}_{3}\right)$ ppm. ${ }^{31} \mathrm{P}$ NMR $\left(121 \mathrm{MHz},\left[\mathrm{D}_{6}\right] \mathrm{DMSO}\right): \delta=$ $29.2 \mathrm{ppm}$. MS $\left(\mathrm{FAB}^{+}\right): m / z=395[\mathrm{M}+\mathrm{H}]^{+}, 789[2 \mathrm{M}+\mathrm{H}]^{+} . \mathrm{MS}$ $\left(\mathrm{FAB}^{-}\right): m / z=393[\mathrm{M}-\mathrm{H}]^{-}, 787[2 \mathrm{M}-\mathrm{H}]^{-}$.

1-[6' -Deoxy-6' -phosphono- $\beta$-D-ribo-(5' $S$ )-hexofuranosyl]uracil (Disodium salt) (10): ${ }^{[3]}$ Compound $9(355 \mathrm{mg}, 0.90 \mathrm{mmol})$ was treated by method B. Reverse-phase column chromatography of the crude materials $\left(\mathrm{H}_{2} \mathrm{O}\right)$ gave $\mathbf{1 0}$ as a white solid $(250 \mathrm{mg}, 82 \%) . R_{\mathrm{f}}(i \mathrm{PrOH} /$ $\left.30 \% \mathrm{NH}_{4} \mathrm{OH} / \mathrm{H}_{2} \mathrm{O}, 7: 1: 2\right)=0.2$. $[\alpha]_{\mathrm{D}}^{20}=-22.7\left(c=0.88, \mathrm{H}_{2} \mathrm{O}\right)$. $\mathrm{C}_{10} \mathrm{H}_{13} \mathrm{~N}_{2} \mathrm{Na}_{2} \mathrm{O}_{9} \mathrm{P} \cdot 0.4 \mathrm{H}_{2} \mathrm{O}$ (389.21): C 30.85, H 3.57, N 7.19, P 7.95; found C 31.15, H 4.07, N 7.26, P 8.19. UV/Vis $\left(\mathrm{H}_{2} \mathrm{O}\right): \lambda_{\max }$ $\left(\varepsilon, \mathrm{dm}^{3} \mathrm{~mol}^{-1} \mathrm{~cm}^{-1}\right)=259(10600), 228(2300) \mathrm{nm} .{ }^{1} \mathrm{H} \mathrm{NMR}$ $\left(300 \mathrm{MHz}, \mathrm{D}_{2} \mathrm{O}\right): \delta=7.83(\mathrm{~d}, J=8.1 \mathrm{~Hz}, 1 \mathrm{H}, 6-\mathrm{H}), 5.87(\mathrm{~d}, J=$ 
$\left.5.3 \mathrm{~Hz}, 1 \mathrm{H}, 1^{\prime}-\mathrm{H}\right), 5.83(\mathrm{~d}, J=8.1 \mathrm{~Hz}, 1 \mathrm{H}, 5-\mathrm{H}), 4.3-4.2(\mathrm{~m}, 2$ $\left.\mathrm{H}, 3^{\prime}-\mathrm{H}, 2^{\prime}-\mathrm{H}\right), 4.10\left(\mathrm{~m}, 1 \mathrm{H}, 5^{\prime}-\mathrm{H}\right), 4.03$ (t, $J=3.2 \mathrm{~Hz}, 1 \mathrm{H}, 4^{\prime}-$ $\mathrm{H}), 1.95-1.70\left(\mathrm{~m}, 2 \mathrm{H}, 66^{\prime}-\mathrm{H}, 6{ }^{\prime \prime}-\mathrm{H}\right) \mathrm{ppm} .{ }^{13} \mathrm{C} \mathrm{NMR}(75 \mathrm{MHz}$, $\left.\mathrm{D}_{2} \mathrm{O}\right): \delta=166.1(\mathrm{C}-4), 151.9(\mathrm{C}-2), 141.9(\mathrm{C}-6), 102.6$ (C-5), 87.9 $\left(\mathrm{C}-1^{\prime}\right), 87.5\left(\mathrm{~d}, J=14.1 \mathrm{~Hz}, \mathrm{C}-4^{\prime}\right), 73.5\left(\mathrm{C}-2^{\prime}\right), 68.7\left(\mathrm{C}-3^{\prime}\right), 67.2(\mathrm{~d}$, $\left.J=3.1 \mathrm{~Hz}, \mathrm{C}-5^{\prime}\right), 31.6\left(\mathrm{~d}, J=131.4 \mathrm{~Hz}, \mathrm{C}-6^{\prime}\right) \mathrm{ppm} .{ }^{31} \mathrm{P}$ NMR $\left(121 \mathrm{MHz}, \mathrm{D}_{2} \mathrm{O}\right): \delta=20.6 \mathrm{ppm}$. MS $\left(\mathrm{FAB}^{-}\right): m / z=337[\mathrm{M}-2 \mathrm{Na}$ $+\mathrm{H}]^{-}, 359[\mathrm{M}-\mathrm{Na}]^{-}$.

1-[6' -Deoxy-6' -diethylphosphono- $\beta$-D-ribo-(5' R/S)-hexofuranosyl]uracil (11): Protected $\beta$-hydroxyphosphonate 8 (1.84 g, $4.24 \mathrm{mmol})$, obtained from the Luche reaction and containing $56 \%$ of the $(R)$ isomer, was dissolved in an aqueous solution of $70 \%$ trifluoroacetic acid $(37 \mathrm{~mL})$ at room temperature, and the mixture was stirred for $3 \mathrm{~h}$. The solution was evaporated under reduced pressure and coevaporated with absolute ethanol. The crude material was purified by reverse-phase chromatography $\left(\mathrm{H}_{2} \mathrm{O} / \mathrm{MeOH}, 0\right.$ to $\left.50 \%\right)$ to give the expected compound as a $60: 40$ mixture of $(R) /(S)$ diastereoisomers $(1.63 \mathrm{~g}, 97.5 \%)$. This mixture was chromatographed again using an isocratic elution $\left(25 \% \mathrm{MeOH}\right.$ in $\left.\mathrm{H}_{2} \mathrm{O}\right)$ to separate the two isomers. Compound $5^{\prime}(R)-\mathbf{1 1}$ was obtained as a white foam $(1.02 \mathrm{~g}$, $61 \%$ ) contaminated by $\approx 10 \%$ of the $5^{\prime}(S)$-isomer. $R_{\mathrm{f}}\left(\mathrm{CH}_{2} \mathrm{Cl}_{2} /\right.$ acetone, 1:2) $=0.07 .[a]_{\mathrm{D}}^{20}=+10.9(c=0.515, \mathrm{MeOH})$. $\mathrm{C}_{14} \mathrm{H}_{23} \mathrm{~N}_{2} \mathrm{O}_{9} \mathrm{P} \cdot 0.2 \mathrm{H}_{2} \mathrm{O}$ (397.71): C 42.26, H 5.93, N 7.04; found $\mathrm{C}$ 41.97, H 5.67, N 6.96. ${ }^{1} \mathrm{H}$ NMR (300 MHz, [D $]$ DMSO): $\delta=11.33$ (br. s, $1 \mathrm{H}$ exchangeable, NH), 7.97 (d, $J=7.97 \mathrm{~Hz}, 1 \mathrm{H}, 6-\mathrm{H}), 5.81$ $\left(\mathrm{d}, J=5.03 \mathrm{~Hz}, 1 \mathrm{H}, 1^{\prime}-\mathrm{H}\right), 5.67$ (d, $\left.J=8.06 \mathrm{~Hz}, 1 \mathrm{H}, 5-\mathrm{H}\right), 5.58$ (d, $J=4.54 \mathrm{~Hz}, 1 \mathrm{H}$ exchangeable, $\left.5{ }^{\prime}-\mathrm{OH}\right), 5.38(\mathrm{~d}, J=4.59 \mathrm{~Hz}, 1 \mathrm{H}$ exchangeable, 2'-OH), 5.12 (br. s, $1 \mathrm{H}$ exchangeable, 3'-OH), 3.99 $3.91\left(\mathrm{~m}, 8 \mathrm{H}, 2^{\prime}-\mathrm{H}, 3^{\prime}-\mathrm{H}, 4^{\prime}-\mathrm{H}, 5^{\prime}-\mathrm{H}, \mathrm{OCH}_{2} \mathrm{CH}_{3}\right), 2.15-1.88$ (m, 2 $\left.\mathrm{H}, 6^{\prime}-\mathrm{H}, 6^{\prime \prime}-\mathrm{H}\right), 1.23\left(\mathrm{t}, J=6.22 \mathrm{~Hz}, 6 \mathrm{H}, \mathrm{OCH}_{2} \mathrm{CH}_{3}\right) \mathrm{ppm} .{ }^{13} \mathrm{C}$ NMR (75 MHz, [D $]$ DMSO): $\delta=163.0$ (C-4), 150.7 (C-2), 140.5 (C-6), $101.8(\mathrm{C}-5), 87.3\left(\mathrm{C}-1^{\prime}\right), 86.5\left(\mathrm{~d}, J=9.3 \mathrm{~Hz}, \mathrm{C}-4^{\prime}\right), 73.6(\mathrm{C}-$ $\left.2^{\prime}\right), 70.6\left(\mathrm{C}-3^{\prime}\right), 65.2\left(\mathrm{C}-5^{\prime}\right), 61.1,60.8(2 \mathrm{~d}, J=6.15 \mathrm{~Hz}$, $\mathrm{OCH}_{2} \mathrm{CH}_{3}$ ), 29.8 (d, $\left.J=136.3 \mathrm{~Hz}, \mathrm{C}-6^{\prime}\right), 16.2,16.1$ (d, $J=5.89 \mathrm{~Hz}$, $\left.\mathrm{OCH}_{2} \mathrm{CH}_{3}\right)$ ppm. ${ }^{31} \mathrm{P}$ NMR (121 MHz, [D $]$ DMSO): $\delta=28.6 \mathrm{ppm}$. MS $\left(\mathrm{ESI}^{+}\right): m / z=395[\mathrm{M}+\mathrm{H}]^{+}, 789[2 \mathrm{M}+\mathrm{H}]^{+}$. MS $\left(\mathrm{ESI}^{-}\right): \mathrm{m} / \mathrm{z}$ $=393[\mathrm{M}-\mathrm{H}]^{-}, 787[2 \mathrm{M}-\mathrm{H}]^{-}$. HRMS $\left(\mathrm{ESI}^{+}\right)$. calcd. for $\mathrm{C}_{14} \mathrm{H}_{24} \mathrm{~N}_{2} \mathrm{O}_{9} \mathrm{P}[\mathrm{M}+\mathrm{H}]^{+}$395.1219; found 395.1220.

1-[6'-Deoxy-6' -phosphono- $\beta$-D-ribo-(5' $R)$-hexofuranosyl]uracil (Sodium salt) (12): Compound 11 (66 mg, $0.18 \mathrm{mmol})$ was treated by method B. Reverse-phase column chromatography of the crude materials $\left(\mathrm{H}_{2} \mathrm{O}\right)$ gave compound $\mathbf{1 2}$ as a white solid $(53 \mathrm{mg}, 82 \%)$ contaminated by $9 \%$ of the $5^{\prime}(S)$-isomer. $R_{\mathrm{f}}\left(i \mathrm{PrOH} / \mathrm{NH}_{4} \mathrm{OH} 30 \% /\right.$ $\left.\mathrm{H}_{2} \mathrm{O}, 7: 1: 2\right)=0.09 .[a]_{\mathrm{D}}^{20}=+7.1\left(c=0.352, \mathrm{H}_{2} \mathrm{O}\right) . \mathrm{UV} / \mathrm{V}$ is $\left(\mathrm{H}_{2} \mathrm{O}\right)$ : $\lambda_{\text {max }}\left(\varepsilon, \mathrm{dm}^{3} \mathrm{~mol}^{-1} \mathrm{~cm}^{-1}\right)=262$ (9900), 230 (2300) nm. ${ }^{1} \mathrm{H}$ NMR (300 MHz, $\left.\mathrm{D}_{2} \mathrm{O}\right): \delta=7.95$ (d, $\left.J=8.12 \mathrm{~Hz}, 1 \mathrm{H}, 6-\mathrm{H}\right), 5.89$ (d, $J=$ $\left.4.98 \mathrm{~Hz}, 1 \mathrm{H}, 1^{\prime}-\mathrm{H}\right), 5.84(\mathrm{~d}, J=8.09 \mathrm{~Hz}, 1 \mathrm{H}, 5-\mathrm{H}), 4.30$ (dd, $J=$ $\left.5.18 \mathrm{~Hz}, 1 \mathrm{H}, 2^{\prime}-\mathrm{H}\right), 4.21\left(\mathrm{dd}, J=4.98 \mathrm{~Hz}, 1 \mathrm{H}, 3^{\prime}-\mathrm{H}\right), 4.18-4.02$ $\left(\mathrm{m}, 1 \mathrm{H}, 5^{\prime}-\mathrm{H}\right), 4.01\left(\mathrm{dd}, J=3.96 \mathrm{~Hz}, 1 \mathrm{H}, 4^{\prime}-\mathrm{H}\right), 1.90-1.70(\mathrm{~m}, 2$ $\left.\mathrm{H}, 6^{\prime}-\mathrm{H}, 6^{\prime \prime}-\mathrm{H}\right) \mathrm{ppm} .{ }^{13} \mathrm{C}$ NMR $\left(75 \mathrm{MHz}, \mathrm{D}_{2} \mathrm{O}\right): \delta=166.2(\mathrm{C}-4)$, 151.8 (C-2), 142.0 (C-6), $102.4(\mathrm{C}-5), 88.6\left(\mathrm{C}-1^{\prime}\right), 87.0(\mathrm{~d}, J=$ $\left.12.9 \mathrm{~Hz}, \mathrm{C}-4^{\prime}\right), 73.7\left(\mathrm{C}-2^{\prime}\right), 70.3\left(\mathrm{C}-3^{\prime}\right), 67.3$ (d, $\left.J=2.8 \mathrm{~Hz}, \mathrm{C}-5^{\prime}\right)$, $32.0\left(\mathrm{~d}, J=130.0 \mathrm{~Hz}, \mathrm{C}-6^{\prime}\right) \mathrm{ppm} .{ }^{31} \mathrm{P}$ NMR $\left(121 \mathrm{MHz}, \mathrm{D}_{2} \mathrm{O}\right): \delta=$ $20.1 \mathrm{ppm} . \mathrm{MS}\left(\mathrm{ESI}^{+}\right): m / z=339[\mathrm{M}-\mathrm{Na}+2 \mathrm{H}]^{+}, 361[\mathrm{M}+\mathrm{H}]^{+}$, $677[2 \mathrm{M}-2 \mathrm{Na}+3 \mathrm{H}]^{+}, 699[2 \mathrm{M}-\mathrm{Na}+2 \mathrm{H}]^{+} . \mathrm{MS}\left(\mathrm{ESI}^{-}\right): \mathrm{m} / z=$ $337[\mathrm{M}-\mathrm{Na}]^{-}$. HRMS $\left(\mathrm{ESI}^{+}\right)$. calcd. for $\mathrm{C}_{10} \mathrm{H}_{16} \mathrm{~N}_{2} \mathrm{O}_{9} \mathrm{P}[\mathrm{M}-\mathrm{Na}$ $+2 \mathrm{H}]^{+} 339.0593$; found 339.0592 .

1-[6' -Deoxy-6' -phosphono- $\beta$-D-ribo-(5' $S)$-hexofuranosyl]cytosine (Disodium salt) (14): ${ }^{[4]}$ After two co-evaporations with anhydrous pyridine, $\beta$-hydroxyphosphonate $9(270 \mathrm{mg}, 0.69 \mathrm{mmol})$ was dissolved in dry pyridine $(1.4 \mathrm{~mL})$ under an argon atmosphere. Acetic anhydride $(322 \mu \mathrm{L}, 3.43 \mathrm{mmol})$ was added dropwise, and the reac- tion mixture was stirred for $5 \mathrm{~h}$. Water and EtOAc were added to the mixture, and the reaction was quenched with aqueous saturated solution of $\mathrm{NaHCO}_{3}$. Layers were separated, and the aqueous one was extracted three times with EtOAc. The organic layers were combined, dried with $\mathrm{MgSO}_{4}$, filtered, and concentrated. The product obtained was co-evaporated with toluene and dried to give a white foam (338 mg, 95\%). This peracetylated product was directly engaged in the next step (Lawesson's reaction). It was dissolved in dry 1,2-dichloroethane $(5.8 \mathrm{~mL})$ under an argon atmosphere then the Lawesson's reagent $(62.2 \mathrm{mg}, 0.15 \mathrm{mmol})$ was added, and the reaction was heated at reflux overnight. Some more Lawesson's reagent $(62.2 \mathrm{mg}, 0.15 \mathrm{mmol})$ was added to the reaction mixture, and the reaction was stopped $24 \mathrm{~h}$ later. The reaction mixture was concentrated under reduced pressure and purified by column chromatography $\left(\mathrm{CH}_{2} \mathrm{Cl}_{2}\right.$ to $\left.\mathrm{CH}_{2} \mathrm{Cl}_{2} / \mathrm{MeOH}, 95: 5\right)$ to give a yellow oil $(35.5 \mathrm{mg})$. This latter was dissolved in methanolic ammonia $(20 \mathrm{~mL} / \mathrm{mmol})$ and heated overnight at $100^{\circ} \mathrm{C}$ in a sealed vessel under vacuum. Then, the reaction mixture was concentrated under reduced pressure and purified by reverse-phase column chromatography $\left(\mathrm{H}_{2} \mathrm{O}\right)$ to give a white solid $(25.9 \mathrm{mg}, 37 \%)$, which corresponds to 13. Derivative 13 was treated by method B. Reversephase column chromatography of the crude materials $\left(\mathrm{H}_{2} \mathrm{O}\right)$ gave compound $\mathbf{1 4}$ as a white solid $(23 \mathrm{mg}, 85 \%)$ after ionexchange on Dowex $\mathrm{Na}^{+}$and freeze drying. $R_{\mathrm{f}}\left(i \mathrm{PrOH} / \mathrm{NH}_{4} \mathrm{OH}\right.$ $\left.30 \% / \mathrm{H}_{2} \mathrm{O}, \quad 7: 1: 2\right)=0.1 . \quad[\alpha]_{\mathrm{D}}^{20}=-11.3\left(c=0.53, \mathrm{H}_{2} \mathrm{O}\right)$. $\mathrm{C}_{10} \mathrm{H}_{14} \mathrm{~N}_{3} \mathrm{Na}_{2} \mathrm{O}_{8} \mathrm{P} \cdot 0.5 \mathrm{H}_{2} \mathrm{O}$ (390.03): calcd. C 30.78, H 3.87, N 10.77, P 7.94; found $\mathrm{C} 30.54, \mathrm{H} 4.27, \mathrm{~N} 10.62, \mathrm{P} 7.77$. UV/Vis $\left(\mathrm{H}_{2} \mathrm{O}\right): \lambda_{\max }\left(\varepsilon, \mathrm{dm}^{3} \mathrm{~mol}^{-1} \mathrm{~cm}^{-1}\right)=268(8800), 248(6400) \mathrm{nm} .{ }^{1} \mathrm{H}$ NMR $\left(300 \mathrm{MHz}, \mathrm{D}_{2} \mathrm{O}\right): \delta=7.88(\mathrm{~d}, J=7.6 \mathrm{~Hz}, 1 \mathrm{H}, 6-\mathrm{H}), 6.07$ $(\mathrm{d}, J=7.6 \mathrm{~Hz}, 1 \mathrm{H}, 5-\mathrm{H}), 5.96\left(\mathrm{~d}, J=5.4 \mathrm{~Hz}, 1 \mathrm{H}, 1^{\prime}-\mathrm{H}\right), 4.44 .2$ (m, $\left.2 \mathrm{H}, 3^{\prime}-\mathrm{H}, 2^{\prime}-\mathrm{H}\right), 4.20\left(\mathrm{~m}, 1 \mathrm{H}, 5^{\prime}-\mathrm{H}\right), 4.11(\mathrm{t}, J=3.4 \mathrm{~Hz}, 1 \mathrm{H}$, $\left.4^{\prime}-\mathrm{H}\right), 2.00-1.80\left(\mathrm{~m}, 2 \mathrm{H}, 66^{\prime}-\mathrm{H}, 66^{\prime \prime}-\mathrm{H}\right) \mathrm{ppm} .{ }^{13} \mathrm{C} \mathrm{NMR}(75 \mathrm{MHz}$, $\left.\mathrm{D}_{2} \mathrm{O}\right): \delta=166.1(\mathrm{C}-4), 157.8(\mathrm{C}-2), 141.9$ (C-6), 96.5 (C-5), 88.9 $\left(\mathrm{C}-1^{\prime}\right), 87.1\left(\mathrm{~d}, J=14.1 \mathrm{~Hz}, \mathrm{C}-4^{\prime}\right), 73.7\left(\mathrm{C}-2^{\prime}\right), 68.7\left(\mathrm{C}-3^{\prime}\right), 67.2(\mathrm{~d}$, $\left.J=3.1 \mathrm{~Hz}, \mathrm{C}-5^{\prime}\right), 31.5\left(\mathrm{~d}, J=131.1 \mathrm{~Hz}, \mathrm{C}-6^{\prime}\right) \mathrm{ppm} .{ }^{31} \mathrm{P} \mathrm{NMR}$ $\left(121 \mathrm{MHz}, \mathrm{D}_{2} \mathrm{O}\right): \delta=20.5 \mathrm{ppm}$. MS $\left(\mathrm{FAB}^{-}\right): m / z=336[\mathrm{M}-2 \mathrm{Na}$ $+\mathrm{H}]^{-}, 358[\mathrm{M}-\mathrm{Na}]^{-}$.

1-[6'-Deoxy-6' -ethylphosphono- $\beta$-D-ribo-(5' $R)$-hexofuranosyl]cytosine (Sodium salt) (15): After two co-evaporations with anhydrous pyridine, $\beta$-hydroxyphosphonate $11(860 \mathrm{mg}, 0.22 \mathrm{mmol})$ was dissolved in dry pyridine $(4.4 \mathrm{~mL})$ under an argon atmosphere. Acetic anhydride $(1.03 \mathrm{~mL}, 10.91 \mathrm{mmol})$ was added dropwise, and the reaction mixture was stirred for $7 \mathrm{~h}$. The reaction mixture was diluted with water and EtOAc and then neutralized with an aq. saturated solution of $\mathrm{NaHCO}_{3}$. Layers were separated, and the aqueous one was extracted three times with EtOAc. The organic layers were dried with $\mathrm{MgSO}_{4}$, filtered, and concentrated. The product obtained was co-evaporated with toluene and dried to give a white foam $(1.129 \mathrm{~g}, 99 \%)$. This product was directly engaged in the next step. The peracetylated nucleotide $(0.50 \mathrm{~g}, 0.96 \mathrm{mmol})$ was dissolved in dry 1,2-dichloroethane $(29 \mathrm{~mL})$ under an argon atmosphere, then the Lawesson's reagent $(0.622 \mathrm{~g}, 1.54 \mathrm{mmol})$ was added, and the reaction was heated at reflux for $24 \mathrm{~h}$. The reaction mixture was concentrated under reduced pressure and purified by column chromatography $\left(\mathrm{CH}_{2} \mathrm{Cl}_{2}\right.$ to $\left.\mathrm{CH}_{2} \mathrm{Cl}_{2} / \mathrm{MeOH}, 97: 3\right)$ to give a yellow foam $(398.5 \mathrm{mg})$. This latter was dissolved in methanolic ammonia $(15 \mathrm{~mL}, 20 \mathrm{~mL} / \mathrm{mmol})$ and heated overnight at $100{ }^{\circ} \mathrm{C}$ in a sealed vessel under vacuum. Then, the reaction mixture was concentrated under reduced pressure and purified by reverse-phase column chromatography $\left(\mathrm{H}_{2} \mathrm{O}\right)$ followed by ion exchange on Dowex $\mathrm{Na}^{+}$to give a light yellow foam $(270 \mathrm{mg}, 77 \%$ ) corresponding to 15. $R_{\mathrm{f}}\left(i \mathrm{PrOH} / \mathrm{NH}_{4} \mathrm{OH} 30 \% / \mathrm{H}_{2} \mathrm{O}, 7: 1: 2\right)=0.33$. $[\alpha]_{\mathrm{D}}^{20}=$ $+18.8(c=1.01, \mathrm{MeOH})$. UV/Vis $(95 \% \mathrm{EtOH}): \lambda_{\max }(\varepsilon$, 
$\left.\mathrm{dm}^{3} \mathrm{~mol}^{-1} \mathrm{~cm}^{-1}\right)=271(7600), 249(5300) \mathrm{nm} .{ }^{1} \mathrm{H}$ NMR $(300 \mathrm{MHz}$, $\left.\mathrm{D}_{2} \mathrm{O}\right): \delta=7.86(\mathrm{~d}, J=7.58 \mathrm{~Hz}, 1 \mathrm{H}, 6-\mathrm{H}), 5.96(\mathrm{~d}, J=7.53 \mathrm{~Hz}$, $1 \mathrm{H}, 5-\mathrm{H}), 5.83\left(\mathrm{~d}, J=4.44 \mathrm{~Hz}, 1 \mathrm{H}, 1^{\prime}-\mathrm{H}\right), 4.22(\mathrm{dd}, J=4.87 \mathrm{~Hz}$, $\left.1 \mathrm{H}, 2^{\prime}-\mathrm{H}\right), 4.15\left(\mathrm{dd}, J=5.28 \mathrm{~Hz}, 1 \mathrm{H}, 3^{\prime}-\mathrm{H}\right), 4.04\left(\mathrm{~m}, 2 \mathrm{H}, 4^{\prime}-\mathrm{H}\right.$, $\left.5^{\prime}-\mathrm{H}\right), 3.82\left(\mathrm{~m}, 2 \mathrm{H}, \mathrm{OCH}_{2} \mathrm{CH}_{3}\right), 2.00-1.70\left(\mathrm{~m}, 2 \mathrm{H}, 6^{\prime}-\mathrm{H}, 6^{\prime \prime}-\mathrm{H}\right)$, $1.15\left(\mathrm{~m}, 3 \mathrm{H}, \mathrm{OCH}_{2} \mathrm{CH}_{3}\right) \mathrm{ppm} .{ }^{13} \mathrm{C} \mathrm{NMR}\left(75 \mathrm{MHz}, \mathrm{D}_{2} \mathrm{O}\right): \delta=$ 165.8 (C-4), 157.2 (C-2), 142.0 (C-6), 96.2 (C-5), 89.7 (C-1'), 86.2 (d, $\left.J=11.32 \mathrm{~Hz}, \mathrm{C}-4^{\prime}\right), 73.9\left(\mathrm{C}-2^{\prime}\right), 70.0\left(\mathrm{C}-3^{\prime}\right), 66.6\left(\mathrm{C}-5^{\prime}\right), 60.7$ (d, $J=6.04 \mathrm{~Hz}, \mathrm{OCH}_{2} \mathrm{CH}_{3}$ ), 30.6 (d, $\left.J=132.84 \mathrm{~Hz}, \mathrm{C}-6{ }^{\prime}\right), 15.8$ (d, $\left.J=6.04 \mathrm{~Hz}, \mathrm{OCH}_{2} \mathrm{CH}_{3}\right)$ ppm. ${ }^{31} \mathrm{P} \mathrm{NMR}\left(121 \mathrm{MHz}, \mathrm{D}_{2} \mathrm{O}\right): \delta=$ $23.2 \mathrm{ppm}$. MS $\left(\mathrm{ESI}^{+}\right): \mathrm{m} / z=366[\mathrm{M}-\mathrm{Na}+2 \mathrm{H}]^{+}, 388[\mathrm{M}+\mathrm{H}]^{+}$, $731[2 \mathrm{M}-2 \mathrm{Na}+3 \mathrm{H}]^{+}, 753[2 \mathrm{M}-\mathrm{Na}+2 \mathrm{H}]^{+}$. $\mathrm{MS}\left(\mathrm{ESI}^{-}\right): \mathrm{m} / \mathrm{z}=$ $364[\mathrm{M}-\mathrm{Na}]^{-}, 729[2 \mathrm{M}-2 \mathrm{Na}+\mathrm{H}]^{-}$. HRMS $\left(\mathrm{ESI}^{-}\right)$: calcd. for $\mathrm{C}_{12} \mathrm{H}_{19} \mathrm{~N}_{3} \mathrm{O}_{8} \mathrm{P}[\mathrm{M}-\mathrm{H}]^{-}$364.0910; found 364.0905.

1-[6' -Deoxy-6' -phosphono- $\beta$-D-ribo-(5' R)-hexofuranosyl]cytosine (Sodium salt) (16): Derivative 15 (319 $\mathrm{mg}, 0.87 \mathrm{mmol})$ was treated by method B. Reverse-phase column chromatography of the crude materials $\left(\mathrm{H}_{2} \mathrm{O}\right)$ gave compound $\mathbf{1 6}$ as a white solid (226 mg, 72\%). $R_{\mathrm{f}}\left(i \mathrm{PrOH} / \mathrm{NH}_{4} \mathrm{OH} 30 \% / \mathrm{H}_{2} \mathrm{O}, 7: 1: 2\right)=0.08 .[\alpha]_{\mathrm{D}}^{20}=-17.0(c=0.47$, $\left.\mathrm{H}_{2} \mathrm{O}\right)$. UV/Vis $\left(\mathrm{H}_{2} \mathrm{O}\right): \lambda_{\max }\left(\varepsilon, \mathrm{dm}^{3} \mathrm{~mol}^{-1} \mathrm{~cm}^{-1}\right)=266$ (9400), 251 (5100) nm. ${ }^{1} \mathrm{H}$ NMR $\left(300 \mathrm{MHz}, \mathrm{D}_{2} \mathrm{O}\right): \delta=7.92(\mathrm{~d}, J=7.57 \mathrm{~Hz}$, $1 \mathrm{H}, 6-\mathrm{H}), 5.96(\mathrm{~d}, J=7.56 \mathrm{~Hz}, 1 \mathrm{H}, 5-\mathrm{H}), 5.87(\mathrm{~d}, J=4.36 \mathrm{~Hz}, 1 \mathrm{H}$, $\left.1^{\prime}-\mathrm{H}\right), 4.19\left(\mathrm{dd}, J=4.83 \mathrm{~Hz}, 1 \mathrm{H}, 2^{\prime}-\mathrm{H}\right), 4.13(\mathrm{dd}, J=5.20 \mathrm{~Hz}, 1$ $\left.\mathrm{H}, 3^{\prime}-\mathrm{H}\right), 4.03\left(\mathrm{~m}, 1 \mathrm{H}, 5^{\prime}-\mathrm{H}\right), 3.91\left(\mathrm{dd}, J=4.63 \mathrm{~Hz}, 1 \mathrm{H}, 4^{\prime}-\mathrm{H}\right)$, $1.66-1.57$ (m, $\left.2 \mathrm{H}, 66^{\prime}-\mathrm{H}, 66^{\prime \prime}-\mathrm{H}\right)$ ppm. ${ }^{13} \mathrm{C}$ NMR $\left(75 \mathrm{MHz}, \mathrm{D}_{2} \mathrm{O}\right)$ : $\delta=165.8(\mathrm{C}-4), 157.4(\mathrm{C}-2), 141.3(\mathrm{C}-6), 95.9(\mathrm{C}-5), 88.8\left(\mathrm{C}-1^{\prime}\right)$, $86.6\left(\mathrm{~d}, J=14.57 \mathrm{~Hz}, \mathrm{C}-4^{\prime}\right), 74.0\left(\mathrm{C}-2^{\prime}\right), 69.8\left(\mathrm{C}-3^{\prime}\right), 67.7\left(\mathrm{C}-5^{\prime}\right)$, $31.5\left(\mathrm{~d}, J=125.5 \mathrm{~Hz}, \mathrm{C}-6^{\prime}\right)$ ppm. ${ }^{31} \mathrm{P}$ NMR $\left(121 \mathrm{MHz}, \mathrm{D}_{2} \mathrm{O}\right): \delta=$ 18.5 ppm. MS $\left(\mathrm{ESI}^{+}\right): \mathrm{m} / z=338[\mathrm{M}-\mathrm{Na}+2 \mathrm{H}]^{+}, 360[\mathrm{M}+\mathrm{H}]^{+}$. MS $\left(\mathrm{ESI}^{-}\right): m / z=336[\mathrm{M}-\mathrm{Na}]^{-}$. $\mathrm{HRMS}\left(\mathrm{ESI}^{+}\right)$: calcd. for $\mathrm{C}_{10} \mathrm{H}_{17} \mathrm{~N}_{3} \mathrm{O}_{8} \mathrm{P}[\mathrm{M}+\mathrm{H}]^{+}$338.0753; found 338.0753.

Supporting Information (see footnote on the first page of this article): ${ }^{1} \mathrm{H},{ }^{13} \mathrm{C}$, and/or ${ }^{31} \mathrm{P}$ NMR spectra for all new compounds. Methods and references for molecular modeling studies.

\section{Acknowledgments}

This work was supported by grants from Agence de Recherche contre le Cancer (ARC) and Agence Nationale de Recherches contre le Sida (ANRS). M. M. is grateful to the Centre National de la Recherche Scientifique (CNRS) \& the Région Languedoc-Roussillon for her doctoral fellowship. The kind assistance of Mrs. MarieChristine Bergogne for manuscript editing is also acknowledged.
[1] W. B. Parker, Chem. Rev. 2009, 109, 2880-2893.

[2] a) E. De Clercq, Biochem. Pharmacol. 2007, 73, 911-922; b) E. De Clercq, Rev. Med. Virol. 2009, 19, 287-299.

[3] F. Gallier, S. Peyrottes, C. Perigaud, Eur. J. Org. Chem. 2007, 925-933.

[4] a) V. V. Nesterov, O. I. Kolodiazhnyi, Tetrahedron 2007, 63, 6720-6731; b) O. I. Kolodiazhnyi, Tetrahedron: Asymmetry 1998, 9, 1279-1332; c) O. I. Kolodiazhnyi, Tetrahedron: Asymmetry 2005, 16, 3295-3340.

[5] a) K. M. Maloney, J. Y. L. Chung, J. Org. Chem. 2009, 74, 7574-7576; b) R. R. Miburn, K. Mcrae, J. Chan, J. Tedrow, R. Larsen, M. Faul, Tetrahedron Lett. 2009, 50, 870-872.

[6] a) C. Balg, S. P. Blais, S. Bernier, J. L. Huot, M. Couture, J. Lapointe, R. Chenevert, Bioorg. Med. Chem. 2007, 15, 295304; b) K. Narkunan, M. Nagarajan, J. Org. Chem. 1994, 59, 6386-6390; c) M. Ordonez, R. de la Cruz, M. Fernandez-Zertuche, M. A. Munoz-Hernandez, Tetrahedron: Asymmetry 2002, $13,559-562$.

[7] J. B. Epp, T. S. Widlanski, J. Org. Chem. 1999, 64, 293-295.

[8] P. Dauban, C. de Saint-Fuscien, F. Acher, L. Prezeau, I. Brabet, J. P. Pin, R. H. Dodd, Bioorg. Med. Chem. Lett. 2000, 10, 129-133.

[9] M. Ordonez, R. De la Cruz-Cordero, M. Fernandez-Zertuche, M. A. Munoz-Hernandez, O. Garcia-Barradas, Tetrahedron: Asymmetry 2004, 15, 3035-3043.

[10] V. V. Nesterov, O. I. Kolodiazhnyi, Tetrahedron: Asymmetry 2006, 17, 1023-1026.

[11] a) M. J. Comin, J. B. Rodriguez, Tetrahedron 2000, 56, 46394649; b) W. J. Gensler, F. Johnson, A. D. B. Sloan, J. Am. Chem. Soc. 1960, 82, 6074-6081; c) V. E. Marquez, M. I. Lim, C. K. H. Tseng, A. Markovac, M. A. Priest, M. S. Khan, B. Kaskar, J. Org. Chem. 1988, 53, 5709-5714; d) T. Oishi, T. Nakata, Acc. Chem. Res. 1984, 17, 338-344.

[12] a) R. Shannon, Acta Crystallogr., Sect. A 1976, 32, 751-767; b) M. Taniguchi, H. Fujii, K. Oshima, K. Utimoto, Tetrahedron 1995, 51, 679-686.

[13] K. Y. Jung, R. J. Hohl, A. J. Wiemer, D. F. Wiemer, Bioorg. Med. Chem. 2000, 8, 2501-2509.

[14] a) W. L. Sung, J. Org. Chem. 1982, 47, 3623-3628; b) Z. Tocik, I. Dvorakova, R. Liboska, M. Budesinsky, M. Masojidkova, I. Rosenberg, Tetrahedron 2007, 63, 4516-4534.

[15] a) T. Bouisset, G. Gosselin, L. Griffe, J. C. Meillon, R. Storer, Tetrahedron 2008, 64, 6657-6661; b) G. Gosselin, L. Griffe, J. C. Meillon, R. Storer, Tetrahedron 2006, 62, 906-914.

[16] a) M. P. Cava, M. I. Levinson, Tetrahedron 1985, 41, 50615087; b) S. Chambert, I. Gautier-Luneau, M. Fontecave, J.-L. Decout, J. Org. Chem. 2000, 65, 249-253.

[17] G. M. Coppola, Synthesis 1988, 81-84.

[18] A. Hampton, J. Am. Chem. Soc. 1961, 83, 3640-3645.

Received: February 18, 2011

Published Online: June 6, 2011 